\title{
Square planar cobalt(II) hydride versus T-shaped cobalt(I): Structural characterization and dihydrogen activation with PNP-Cobalt Pincer Complexes
}

Lukas S. Merz, Clemens K. Blasius, Hubert Wadepohl and LutzH.Gade*

Anorganisch Chemisches Institut, Universität Heidelberg Im Neuenheimer Feld 270, 69120 Heidelberg (Germany).

\section{Contents}

1 Experimental Procedures 2

2 DFT Calculations $\quad 6$

3 DFT-assisted assignment of the paramagnetic NMR spectra 10

4 X-ray Crystal Structure Determinations $\quad 13$

$\begin{array}{lll}5 & \text { NMR Spectra } & 17\end{array}$

6 IR Spectra 29 


\section{Experimental Procedures}

\section{General Remarks}

All manipulations were performed under an argon atmosphere using standard Schlenk and Glovebox techniques. Glassware was dried by heating to $150{ }^{\circ} \mathrm{C}$ overnight and evacuating during cooling down. The commercially available argon of purity 5.0 was further dried by passing over $\mathrm{P}_{2} \mathrm{O}_{5}$ granulate. Solvents were either dispensed from a MBRAUN-SPS-800 or in case of benzene dried over sodiumbenzophenone ketyl and stored over potassium mirrors. Air-sensitive compounds were stored and handled in a Glovebox Workstation (Unilab-2000, MBRAUN). Chemicals were either procured from the Chemical Institute of the University of Heidelberg or purchased from Sigma-Aldrich, abcr or Acros. Substrates were dried using $\mathrm{CaH} 2$ and degassed by three freeze-pump-thaw cycles prior to use. $\mathrm{CoCl}_{2}(\text { thf })_{1.1}$ was prepared by extraction of commercial anhydrous $\mathrm{CoCl}_{2}$ with THF. Deuterated solvents were purchased from Deutero or Sigma-Aldrich and dried over sodium.

1H and $13 \mathrm{C}$ spectra were recorded on a Bruker Avance III 600 or a Bruker II 400 spectrometer. Chemical shifts $(\delta)$ were measured relative to the shift of the residual protons in the deuterated solvent or the solvent resonances (benzene- $d_{6}: \delta=7.16$ ppm for ${ }^{1} \mathrm{H}, \delta=128.06 \mathrm{pp}$, for ${ }^{13} \mathrm{C}$; toluene- $d 8$ : $\arg 1 \delta=2.09 \mathrm{ppm}$ for ${ }^{1} \mathrm{H}, \delta=20.04 \mathrm{ppm}$ for ${ }^{13} \mathrm{C}$ ) and are given in parts per million (ppm). Signals were assigned by a combination of DFT modelling with analytical data such as line broadening, coupling pattern and relative intensity. Coupling constants, ${ }^{\mathrm{n}} \mathrm{J}$, are stated in Hertz $(\mathrm{Hz})$ and the signal patterns are denoted according to usual conventions (singlet $=\mathrm{s}$, doublet $=\mathrm{d}$, etc.). If not stated otherwise, all spectra were recorded at room temperature.

Microanalyses $(\mathrm{C}, \mathrm{H}, \mathrm{N})$ were performed at the Department of Organic Chemistry at the University of Heidelberg on an Elementar vario MICROCube machine

IR spectra were either recorded on a Varian 3100 Ft-IR (Excalibur Series) or a Mettler Toledo ReactIR15 with aSiComp probehead, connected withDST-AgX-fiber optics, $9.5 \mathrm{~mm}$ diameter. 
$\operatorname{Pr}\left(\right.$ CbzPNP)CoD (3 $3^{\text {Pr }}-$ Co"D)

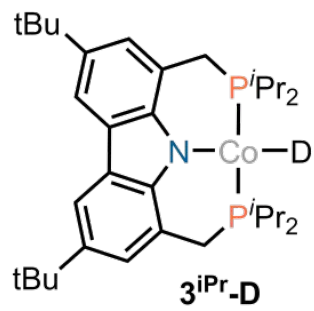

A solution of ${ }^{i \mathrm{Pr}}\left({ }^{\mathrm{Cbz} P N P}\right) \mathrm{CoBn}\left(10 \mathrm{mg}, 15 \mathrm{mmol}, 1.0\right.$ equiv) in benzene- $d_{6}(0.5 \mathrm{~mL})$ was put under a deuterium atmosphere (10 bar) for $10 \mathrm{~min}$. Then all volatiles were removed, and the product was obtained as an orange solid $(4 \mathrm{mg}, 7 \mu \mathrm{mol}, 46 \%)$.

${ }^{1} \mathbf{H}$ NMR (600.13 MHz, benzene- $\left.\boldsymbol{d}_{6}, 295 \mathrm{~K}\right): \delta[\mathrm{ppm}]=47.79\left(\mathrm{~s}, 3 \mathrm{H}, \mathrm{CH} 2 / \mathrm{CH}\left(\mathrm{CH}_{3}\right)_{2}\right), 36.50$

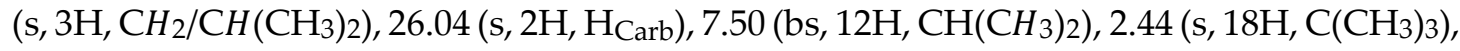
$0.00\left(\mathrm{~s}, 2 \mathrm{H}, \mathrm{H}_{\mathrm{Carb}}\right),-8.06\left(\mathrm{bs}, 12 \mathrm{H}, \mathrm{CH}\left(\mathrm{CH}_{3}\right)_{2}\right)$.

\section{Reaction of $4^{\mathrm{AB}}-\mathrm{Co}^{\mathrm{I}}$ with HD gas:}
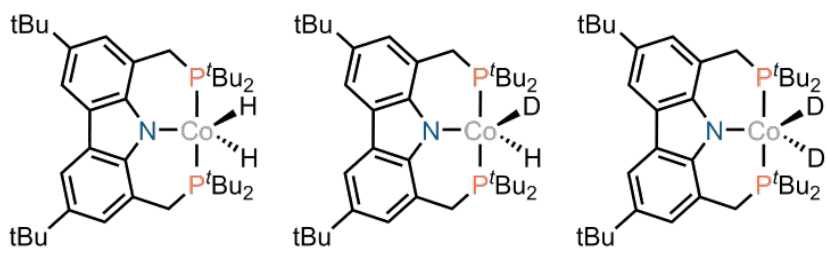

A pressure NMR tube with a solution of $4^{\mathrm{tBu}}-\mathrm{Co}^{\mathrm{I}}(5.0 \mathrm{mg}, 7.7 \mu \mathrm{mol})$ in toluene- $d_{8}(0.5 \mathrm{~mL})$ was cooled to $-120^{\circ} \mathrm{C}$. At this temperature, the tube was pressurized with deuterium hydride gas (4bar) and allowed to warm to ambient temperatures.

${ }^{1} \mathrm{H}$ NMR (399.89 MHz, benzene- $\left.\boldsymbol{d}_{6}, 295 \mathrm{~K}\right): \delta[\mathrm{ppm}]=8.3\left(\mathrm{~s}, 2 \mathrm{H}, \mathrm{H}_{\text {Carb-2,7) }}, 7.4\right.$ (s, 2H, $\mathrm{H}_{\text {Carb-2,7) }}$, $4.5\left(\mathrm{~s}, 2 \mathrm{H}, \mathrm{H}_{2}\right.$ gas $), 4.5(\mathrm{t}, J=42.6 \mathrm{~Hz}, 2 \mathrm{H}, \mathrm{HDgas}), 3.3\left(\mathrm{~s}, 4 \mathrm{H}, \mathrm{CH}_{2}\right), 1.6\left(\mathrm{~s}, 18 \mathrm{H}, \mathrm{C}\left(\mathrm{CH}_{3}\right) 3\right), 1.1(\mathrm{~s}$, $\left.36 \mathrm{H}, \mathrm{C}\left(\mathrm{CH}_{3}\right)_{3}\right),-37.1--37.7$ (m, 2H, Co-2H/Co-HD).

${ }^{2} \mathrm{H}$ NMR (92.12 MHz, benzene- $\left.\boldsymbol{d}_{6}, 295 \mathrm{~K}\right): \delta[\mathrm{ppm}]=4.7$ (d, $J=42.7 \mathrm{~Hz}, 1 \mathrm{D}, \mathrm{HD}$ gas), 4.6 (s, $1 \mathrm{D}, \mathrm{D}_{2}$ gas), -36.5 (bs, 1D, Co-HD/Co2D). 


\section{Reaction of ${ }^{P r}(\mathrm{Cbz} P N P) C o C l$ with Phenethylmagnesiumchloride}

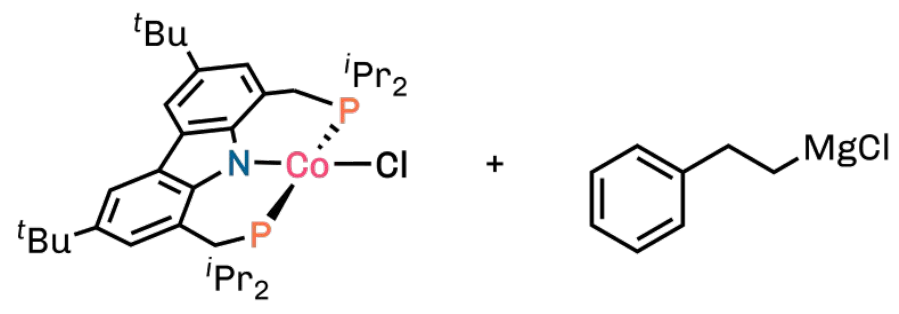

Toa solution of ${ }^{i \mathrm{Pr}}\left({ }^{\mathrm{Cbz}} \mathrm{PNP}\right) \mathrm{CoBn}\left(20 \mathrm{mg}, 33 \mu \mathrm{mol}, 1.0\right.$ equiv) in benzene- $d_{6}(0.5 \mathrm{~mL})$, a solution of phenethylmagnesium chloride ( $35 \mu \mathrm{L}, 35 \mu \mathrm{mol}, 1.1$ equiv., $1 \mathrm{M}$ in THF) was added which resulted in an immediate color change and the formation of ${ }^{i \mathrm{Pr}}\left({ }^{\mathrm{Cbz}} \mathrm{PNP}\right) \mathrm{CoH}, 3{ }^{i \mathrm{Pr}}-\mathrm{Co}^{\mathrm{II}} \mathrm{H}$. In order to analyze the formation of styrene, the reaction mixture was filtrated over a silica plug. ${ }^{1} \mathrm{H}$ NMR comparison with pure styrene confirmed the $\beta$-Helimation under formation of styrene.

${ }^{i P r}\left({ }^{\mathrm{Cbz}} \mathrm{PNP}\right) \mathrm{CoH}, 3^{\text {iPr }}-\mathrm{Co}^{\mathrm{II}} \mathrm{H}$ :

${ }^{1} \mathrm{H}$ NMR (600.13 MHz, benzene- $\left.\boldsymbol{d}_{6}, 295 \mathrm{~K}\right): \delta[\mathrm{ppm}]=48.1\left(\mathrm{~s}, 4 \mathrm{H}, \mathrm{CH}_{2} / \mathrm{CH}\left(\mathrm{CH}_{3}\right)_{2}\right), 37.7(\mathrm{~s}$, $\left.4 \mathrm{H}, \mathrm{CH}_{2} / \mathrm{CH}\left(\mathrm{CH}_{3}\right)_{2}\right), 26.0$ (s, 2H, $\mathrm{H}_{\text {Carb-3/5) }}, 7.6$ (bs, 12H, $\left.\mathrm{CH}\left(\mathrm{CH}_{3}\right)_{2}\right)(\mathrm{bs}, 12 \mathrm{H}, \mathrm{PCH}(\mathrm{CH} 3) 2), 2.4$ $\left(\mathrm{s}, 18 \mathrm{H}, \mathrm{C}\left(\mathrm{CH}_{3}\right)_{3}\right), 0.0\left(\mathrm{~s}, 2 \mathrm{H}, \mathrm{H}_{\text {Carb-3/5) }},-8.1\right.$ (bs, $\left.12 \mathrm{H}, \mathrm{CH}\left(\mathrm{CH}_{3}\right)_{2}\right)$.

${ }^{1} \mathrm{NMR}$ after $\mathrm{SiO}_{2}$ :

${ }^{1}$ H NMR (600.13 MHz, benzene- $\left.\mathbf{d}_{6}, 295 \mathrm{~K}\right): \delta[\mathrm{ppm}]=7.23(\mathrm{~d}, J=7.3 \mathrm{~Hz}, 1 \mathrm{H}), 7.10(\mathrm{dd}, J=$ $8.5,7.0 \mathrm{~Hz}, 1 \mathrm{H}), 7.06(\mathrm{q}, J=6.7 \mathrm{~Hz}, 2 \mathrm{H}), 6.58(\mathrm{dd}, J=17.6,10.8 \mathrm{~Hz}, 1 \mathrm{H}), 5.60(\mathrm{~d}, J=17.6 \mathrm{~Hz}, 1 \mathrm{H})$, $5.07(\mathrm{~d}, J=10.9 \mathrm{~Hz}, 1 \mathrm{H})$. 


\section{Reaction of ${ }^{P r}(C b z P N P) C o D$ with Styrene}

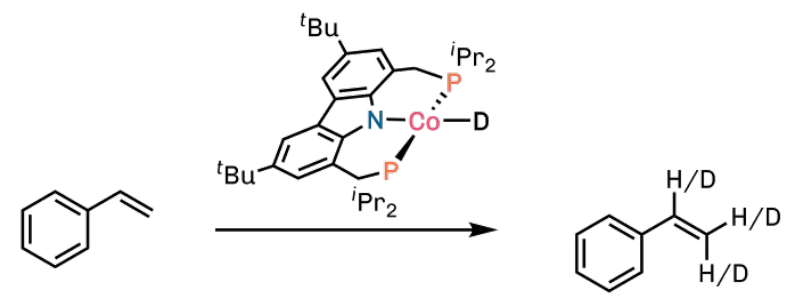

A solution of ${ }^{i \mathrm{Pr}}\left({ }^{\mathrm{Cbz}} \mathrm{PNP}\right) \mathrm{CoBn}(12 \mathrm{mg}, 20 \mu \mathrm{mol}, 1.0$ equiv) in diethylether $(0.5 \mathrm{~mL})$ was put under an atmosphere of deuterium gas $(10 \mathrm{bar})$, generating ${ }^{i \operatorname{Pr}}\left({ }^{\mathrm{Cbz}} \mathrm{PNP}\right) \mathrm{CoD}$. Then, the $\mathrm{D}_{2}$ gas was removed and neat styrene $(2.0 \mu \mathrm{L}, 20 \mu \mathrm{mol}, 1.1$ equiv.) was added and stirred for $60 \mathrm{~min}$. Subsequently, the mixture was filtrated over silica.

${ }^{2}$ H NMR (92.12 MHz, 295 K): $\delta$ [ppm] = 6.65 (bs, $\mathrm{PhCDCH}_{2}$ ), 5.58 (s, PhCHCDH), 5.03 (s, $\mathrm{PhCHCHD)}$.

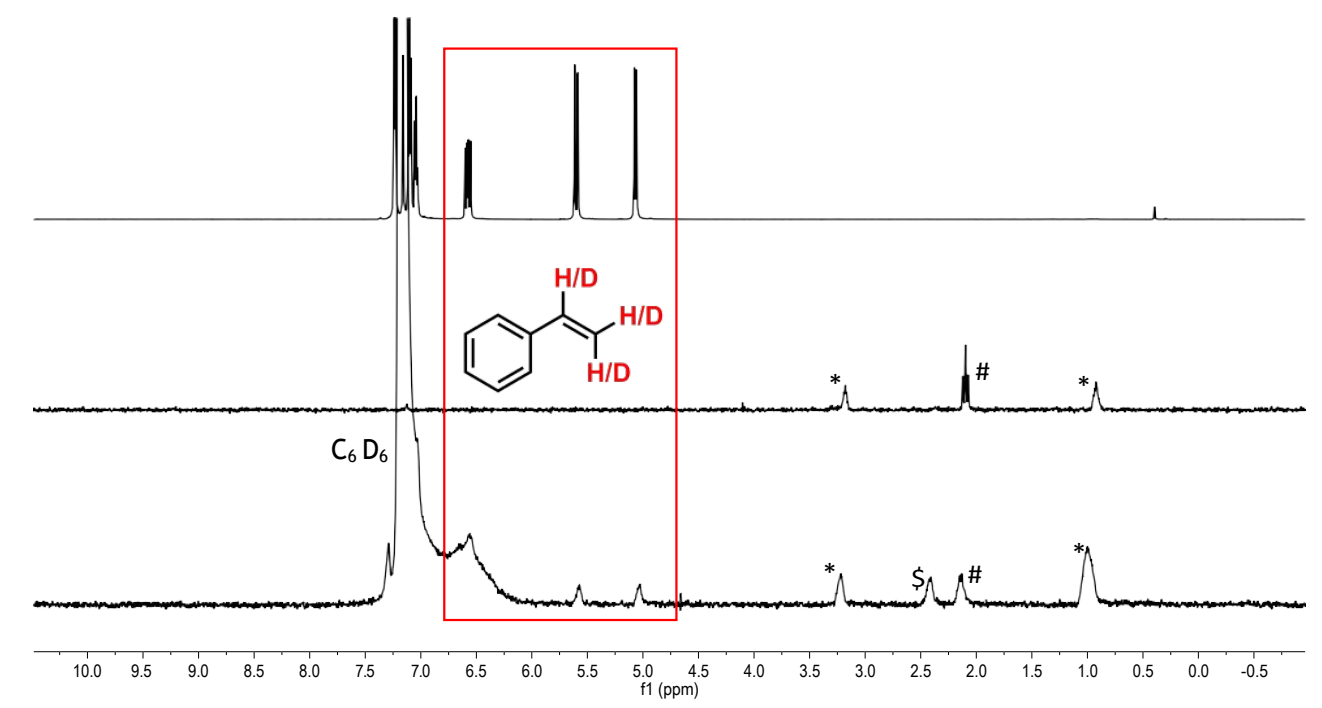

Figure S1: Top: ${ }^{1} \mathrm{H}$ NMR spectrum of styrene in benzene- $d_{6}$. Middle: ${ }^{2} \mathrm{H}$ NMR spectrum after ${ }_{i \mathrm{Pr}}\left({ }^{\mathrm{Cbz}} \mathrm{PNP}\right) \mathrm{CoBn}$ was put under $\mathrm{D}_{2}$ pressure (10 bar) for $15 \mathrm{~min}$, identifying resonances of a partially deuterated and oxidized ligand. Bottom: ${ }^{2} \mathrm{H}$ NMR spectrum of the reaction of ${ }^{i \mathrm{Pr}}\left({ }^{\mathrm{Cbz}} \mathrm{PNP}\right) \mathrm{CoD}$ (generated from $\left.{ }^{i \mathrm{Pr}}\left({ }^{\mathrm{Cbz}} \mathrm{PNP}\right) \mathrm{CoBn}\right)$ with styrene after $1 \mathrm{~h}$. Middle and Bottom spectra were recorded after filtration over silica (\#$\mathrm{PhCH}_{2} \mathrm{D} ;{ }^{*}$ - partially deuterated ligand; $\$$ - unidentified byproduct). 


\section{DFT Calculations}

All calculations were carried out using DFT employing the Gaussian $09^{1}$ package and the $\mathrm{B} 3 \mathrm{LYP}^{2,3} \mathrm{PBE}^{4}$ as well as the $\mathrm{M} 06 \mathrm{~L}^{5}$ functional.

For DFT-assisted paramagnetic NMR analysis, the unrestricted B3LYP $\mathrm{P}^{2,3}$ functional has proven reliable for the estimation of the residual spin densities ${ }^{6-8}$ and was therefore utilized for optimization and frequency calculations. The atoms $\mathrm{C}, \mathrm{H}, \mathrm{N}, \mathrm{P}$, and $\mathrm{Cl}$ were represented by Pople's split-valence basis set, 6-311G(d,p), ${ }^{9}$ while Ahlrich's redefined triple zeta basis set, Def2TZVP, ${ }^{10}$ was employed for Co.

In the course of the investigation into the HD exchange mechanism computations were carried out with the B3LYP, ${ }^{2,3}$ the PBE0 ${ }^{4}$ as well as the M06L ${ }^{5}$ functional. Alike the NMR shift calculations, during the optimization calculations cobalt was represented by the Def2 $\mathrm{TZVP}^{10}$ while the $6311 \mathrm{G}(\mathrm{d}, \mathrm{p})^{9}$ basis set was used for all other atoms. The convergence criterium was set to tight for all optimization reactions and ultrafine was selected for the integration grid. When empirical dispersion correction was included, Becke-Johnson damping (D3BJ) was chosen for B3LYP calculations while D3 was chosen for M06L computations as implemented in Gaussian 09, Revision D01. ${ }^{11,12}$ For final structures discussed in the main text, frequency calculations were carried out using Def2TZVP for all atoms. Using the same basis set, the solvent (benzene) influence was taken into consideration through single-point calculations on the gas-phase optimized geometries with SCRF calculations within the PCM model. ${ }^{13}$ Energies are reported as Gibbs free energies, including the gas-phase Gibbs contributions at $298 \mathrm{~K}$ and $8 \mathrm{~atm}$. Vibrational models below $100 \mathrm{~cm}^{-1}$ were replaced by $100 \mathrm{~cm}^{-1}$ as suggested by Cramer ${ }^{14}$ using the Goodvibes ${ }^{15}$ program developed by Paton and Funes-Ardoiz.

In order to choose a functional for the HD exchange reaction, complex $4^{\mathrm{tBu}}-\mathrm{Co}^{\mathrm{I}}$ was optimized using B3LYP, PBE0 and M06L with two different basis sets for non-metal atoms (6311G(d,p), Def2SVP). The bond lengths for N-Co, P1-Co and P2-Co were then compared to the bond lengths obtained from $X$-ray diffraction analysis (cf. TableS1).

Additionally, the relative energies for $6^{\mathrm{tBu}}-\mathrm{Co}^{\mathrm{III}}\left(\mathrm{H}_{2}, 4^{t \mathrm{Bu}}-\mathrm{Co}^{\mathrm{I}}\right.$ and A-1 were determined with and without empirical dispersion correction (cf. Figure S2). 
Table S1: Benchmarking of three functionals with the determined bond lengths (N-Co, P1$\mathrm{Co}$ and $\mathrm{P} 2-\mathrm{Co})$ of $4^{\mathrm{tBu}}-\mathrm{Co}^{\mathrm{I}}$ through $\mathrm{X}$ ray diffraction analysis. The error for the calculated bond lengths was estimated at $0.001 \AA$.

\begin{tabular}{|c|c|c|c|c|}
\hline & & \multicolumn{3}{|c|}{$6-311 G(d, p)$} \\
\hline Bond & X-Ray $[\AA]$ & B3LYP [Å] & PBE0 [Å] & M06L $[\AA]$ \\
\hline N-Co & $1.9872(19)$ & 2.032 & 2.018 & 2.049 \\
\hline P1-Co & $2.2351(7)$ & 2.310 & 2.279 & 2.239 \\
\hline P2-Co & $2.2273(6)$ & 2.300 & 2.270 & 2.239 \\
\hline \multicolumn{2}{|c|}{ Total deviation [\%] } & $2.966 \pm 0.134$ & $1.819 \pm 0.133$ & $1.279 \pm 0.128$ \\
\hline & & \multicolumn{3}{|c|}{ Def2SVP } \\
\hline Bond & X-Ray $[\AA ̊]$ & B3LYP $[\AA ̊]$ & PBE0 [Å] & M06L [Å] \\
\hline $\mathrm{N}-\mathrm{Co}$ & 1.9872(19) & 2.027 & 2.014 & 2.049 \\
\hline P1-Co & $2.2351(7)$ & 2.305 & 2.276 & 2.245 \\
\hline P2-Co & $2.2273(6)$ & 2.295 & 2.270 & 2.239 \\
\hline \multicolumn{2}{|c|}{ Total deviation [\%] } & $2.733 \pm 0.134$ & $1.708 \pm 0.133$ & $1.389 \pm 0.134$ \\
\hline
\end{tabular}



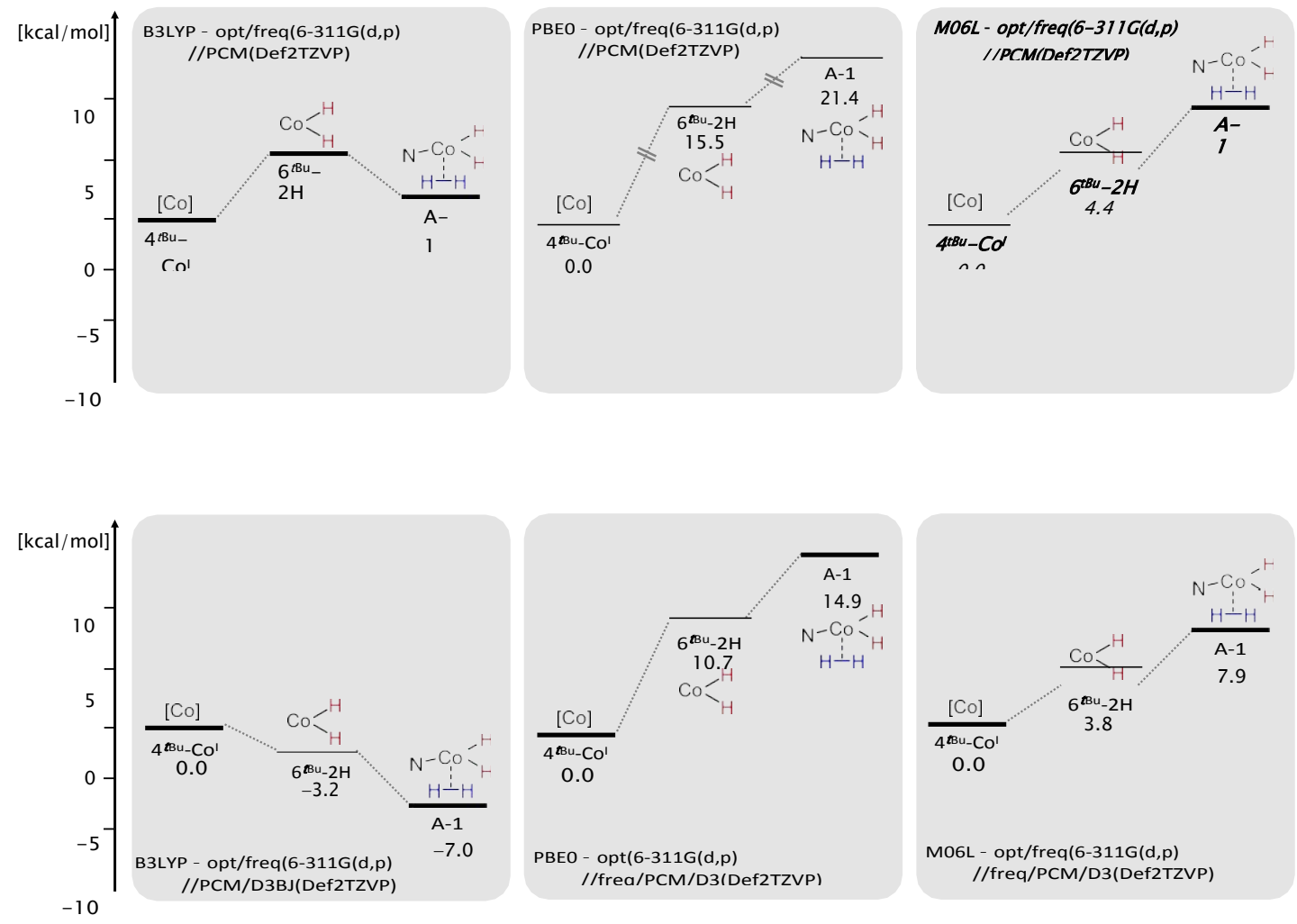

Figure S2: Comparison of the relative energies for the functionals B3LYP, PBE0 and M06L with (bottom) and without (top) empirical dispersion correction

Despite that B3LYP has proven reliable for the calculation of paramagnetic shifts, the calculation of the bond lengths showed the largest deviations from the $X$-ray determined bond lengths. Moreover, B3LYP predicted intermediate A-1 to be lower in energy than the dihydride complex $\mathbf{6}^{\mathbf{t B u}}-\mathrm{Co}^{\mathrm{III}}(\mathbf{H})_{2}$. However, the occurrence of A-1 could not be validated experimentally as the detection of this species by NMR (temperature range: 193-333 K) remained unsuccessful despite numerous attempts. For PBE0 and M06L the deviations of the bond lengths are similar, despite M06L turned out to be more accurate. Assessing the computed structures for PBE0 and M06L (cf. Figure S2), the relative energy for $6^{\mathbf{t B u}}-\mathrm{Co}^{\mathrm{III}}(\mathbf{H})_{2}$ appears to be overestimated in the case of PBE0 $(\Delta \mathrm{G}=\approx 10-15 \mathrm{kcal} / \mathrm{mol})$. On the contrary, M06L gave reasonable relative energies for both $6^{\mathrm{tBu}}-\mathrm{Co}^{\mathrm{III}}(\mathrm{H})_{2}$ and $\mathrm{A}-1$, wherefore, the M06L functional was chosen for further calculations. 


\section{Rotation of $\mathrm{H}_{2}$ in B-3}

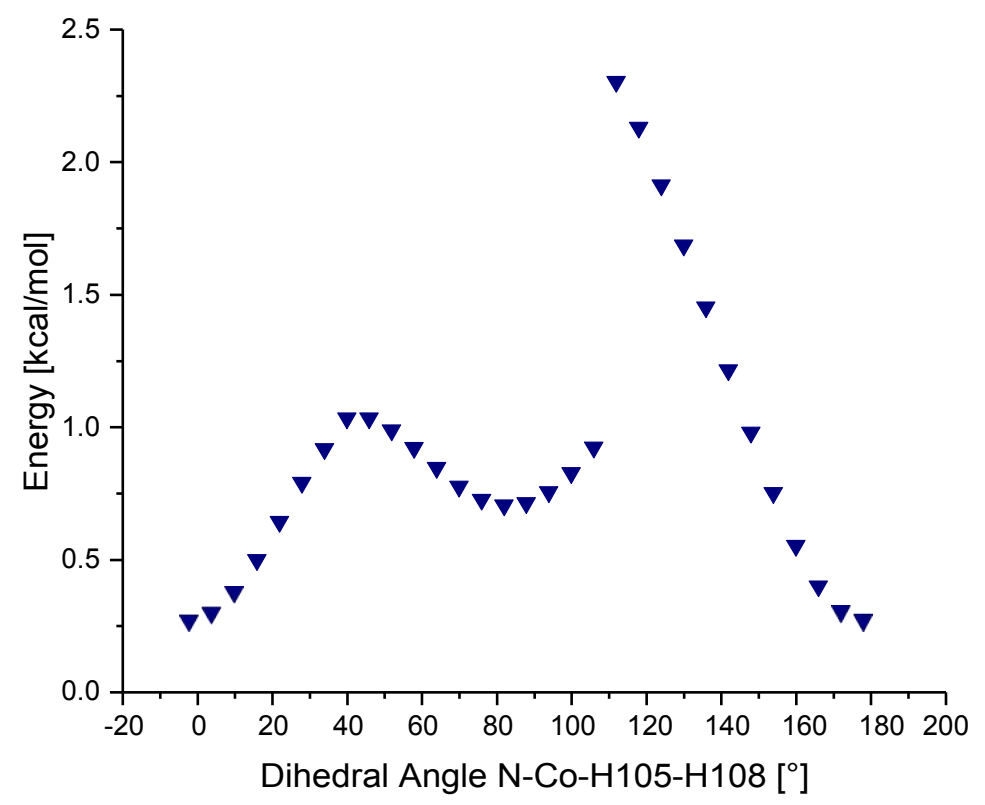

Figure S3: Total energy scan of dihedral angle N-Co-H105-H108 in structure B-3 giving a rough estimation of the energy barrier for the rotation of the coordinated $\mathrm{H}_{2}$ molecule. 


\section{DFT-assisted assignment of the paramagnetic NMR} spectra

The observed chemical shift $\delta_{o b s}$ in a paramagnetic molecule can be expressed as the sum of the diamagnetic shift $\delta_{\text {dia }}$ and a temperature dependent paramagnetic contribution $\delta_{h f .}{ }^{16,17}$

$$
\delta_{o b s}=\delta_{d i a}+\delta_{h f}(1)
$$

The hyperfine shift itself may be written as shown in eq. 2, involving the total electron spin $S$, the Bohr magneton $\mu_{B}$, the Boltzmann constant $k$, the nuclear gyromagnetic ratio $\gamma_{N}$, and the matrices $g$ and $\mathrm{A}$ of the $\mathrm{g}$ - and A-hyperfine tensors. ${ }^{16}$

$$
\delta_{h f}=\frac{\left(S(S+1) \underline{\mu}_{B}\right)}{3 k T \gamma_{N}} g A(2)
$$

Although the product of the matrices $g$ and A gives rise to several isotropic and anisotropic contributions to $\delta_{h f}$, it has been shown that the expression of $\delta_{h f}$ can be simplified in a good approximation to eq. 3 , comprising the Fermi-contact shift $\delta_{\text {con }}$ and the pseudocontact shift $\delta_{\text {dip }}$ as the two main contributions. ${ }^{16,18-20}$

$$
\delta_{h f}=\delta_{c o n}+\delta_{\text {dip }}(3)
$$

The Fermi-contact shift $\delta_{\text {con }}$ is due to the delocalization of unpaired spin density through covalent bonds and directly proportional to the respective residual spin density $\varrho_{\alpha \beta}$ at the nucleus of interest: ${ }^{16,21}$

$$
\delta_{c o n}=\frac{\left(\mu o \mu^{2} g^{2}\right)}{B e} \frac{(S+1)}{9^{k}}
$$

Therein, $\mu_{0}$ represents the vacuum permeability and $g_{e}$ the g-factor of a free electron. By combining the natural constants in the constant $m=23.5 \cdot 106 \mathrm{ppm} \mathrm{Kau}{ }^{-1}$ eq. 5 is obtained:

$$
\delta_{c o n}=m \frac{(S+1)}{T} Q_{\alpha \beta}(5)
$$

In contrast, the pseudocontact shift $\delta_{\text {dip }}$ results from dipolar interactions between the magnetic moment of the unpaired electrons and the magnetic moment of the respective nucleus through space.13 This interaction is proportional to $\mathrm{r}^{-6}$, with $\mathrm{r}$ being the distance between the paramagnetic center and the NMR active nucleus. 15 As this dependence leads for many $3 \mathrm{~d}$ metal complexes to negligibly small $\delta_{\text {diup }}$ values in comparison with the Fermi-contact shift $\delta_{\text {con }}$, the total chemical shift $\delta_{\text {obs }}$ can be approximated as the sum of $\delta_{\text {dia }}$ and $\delta_{\text {con }}$ in these cases: ${ }^{22}$

$$
\delta_{o b s}=\delta_{d i a}+\delta_{c o n}(6)
$$


Assignment of Paramagnetic NMR Spectra Eq. 6 was exploited for the calculation of chemical shifts. The spin densities $\varrho_{\alpha \beta}$ required for the calculation of the Fermi-contact shift according to eq 5 were extracted from DFT calculations. The diamagnetic contributions $\delta_{\text {obs }}$ were approximated by the experimentally obtained chemicals shifts for the lithiated ligand (PNP)Li. ${ }^{23}$ A complete assignment of the paramagnetic NMR spectra was then achieved based on comparison between experimentally and computationally obtained chemical shifts, observed multiplicities, integral values and line width.

Table S2: Assignment of ${ }^{13} \mathrm{C}$ NMR resonances of complexes $3^{\mathrm{iPr}}-\mathrm{Co}^{\mathrm{II}} \mathrm{H}$ and $4^{t \mathrm{Bu}}-\mathrm{Co}{ }^{\mathrm{I}}$.

\begin{tabular}{lcccccc}
\hline & \multicolumn{3}{c}{$3^{\text {iPr}}-\mathbf{C o}^{\mathrm{II}} \mathbf{H}$} & \multicolumn{3}{c}{$\mathbf{4}^{\text {tBu}}-\mathrm{Co}^{\mathrm{I}}$} \\
\cline { 2 - 7 } & $\delta_{\text {exp }}$ & $\delta_{\text {calc }}(\mathrm{CoH})$ & $\delta_{\text {calc }}\left(\mathrm{Co}^{\mathrm{I}}\right)$ & $\delta_{\text {exp }}$ & $\delta_{\text {calc }}(\mathrm{CoH})$ & $\delta_{\text {calc }}\left(\mathrm{Co}^{\mathrm{I}}\right)$ \\
$\mathrm{C} 1$ & 114.4 & 86.5 & 478.9 & 486.2 & 143.3 & 472.9 \\
$\mathrm{C} 2$ & -97.8 & -34.7 & 98.7 & 53.9 & -188.0 & 93.8 \\
$\mathrm{C} 3 / 5$ & 174.7 & 130.4 & 171.2 & 199.3 & 187.1 & 168.2 \\
$\mathrm{C} 4 / 6$ & 88.6 & 118.3 & 46.6 & 53.1 & 33.7 & 48.6 \\
$\mathrm{C} 5 / 3$ & 195.8 & 130.6 & 198.3 & 222.9 & 232.2 & 195.4 \\
$\mathrm{C} 6 / 4$ & 53.4 & 115.2 & 83.4 & 69.2 & 7.7 & 87.3 \\
$\mathrm{C} 7$ & 15.3 & 36.8 & 8.9 & 4.1 & -4.1 & 9.9 \\
$\mathrm{C} 8$ & 50.4 & 31.2 & 56.1 & 57.8 & 67.0 & 54.7 \\
$\mathrm{C} 9$ & -298.6 & -571.3 & -804.4 & -523.7 & -603.1 & -778.3 \\
$\mathrm{C} 10$ & -32.3 & -129.4 & 528.3 & 535.7 & -168.5 & 404.5 \\
$\mathrm{C} 11 / 12$ & 82.0 & 55.2 & 149.8 & 262.6 & -48.1 & 165.3 \\
$\mathrm{C} 12 / 11$ & 85.0 & 92.5 & 309.6 & - & - & - \\
\hline
\end{tabular}




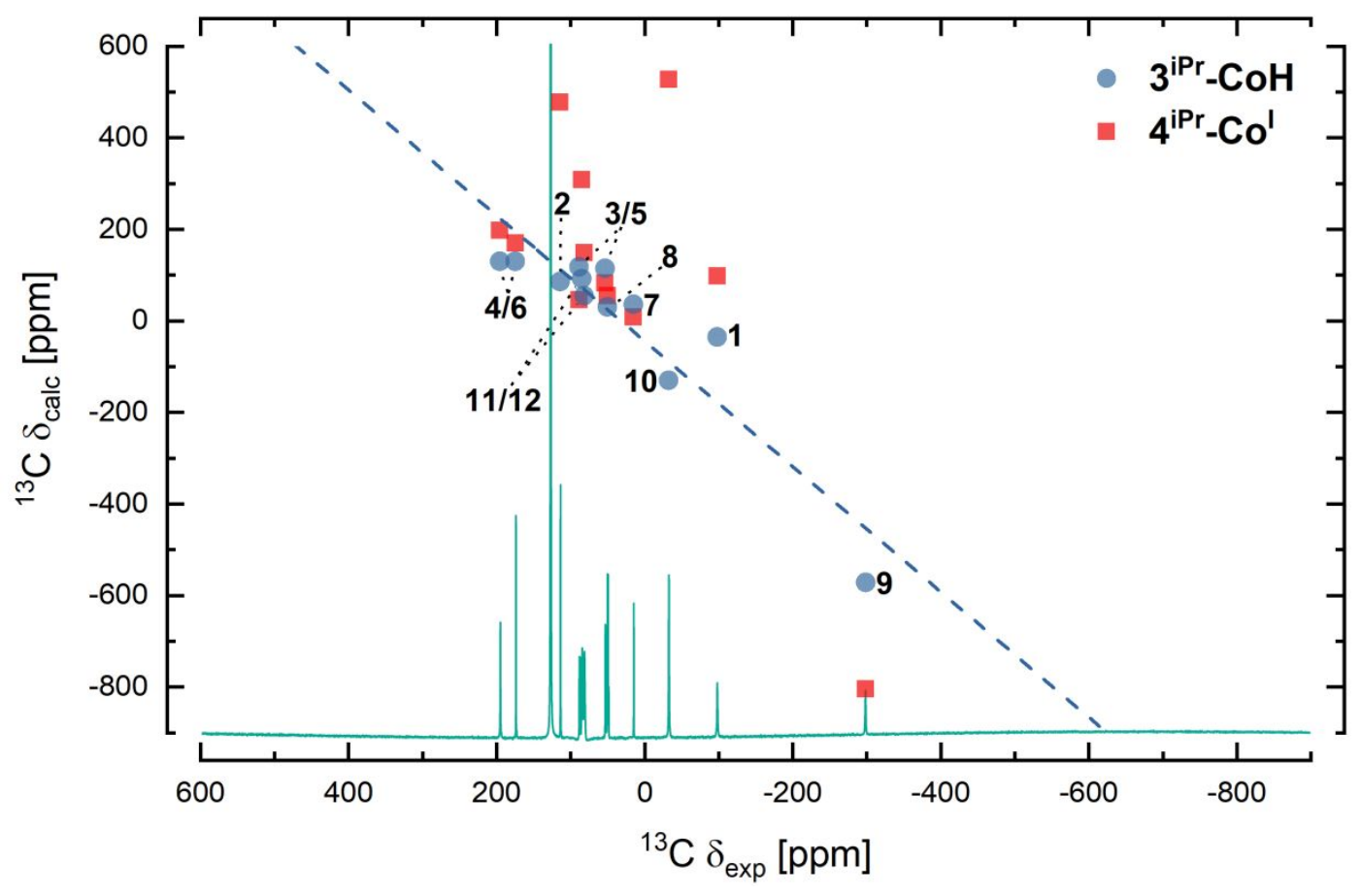

Figure S4: Correlation of experimentally [295 K, $150.92 \mathrm{MHz}, \mathrm{C}_{6} \mathrm{D}_{6}$ ] and computationally [B3LYP/6-311(d,p)+TZVP (only for cobalt)] obtained ${ }^{13} \mathrm{C}$ NMR chemical shifts for the identification and characterization of cobalt hydride $3^{\text {iPr }}-{ }_{-}{ }^{\mathrm{II}} \mathbf{H}$. Uncertain sig-nal assignments are labelled with a slash. The dashed lines show the best linear fit for the respective, identified product: $3^{\text {iPr }}-\mathrm{Co}^{\mathrm{II}} \mathbf{H}$ : slope $\mathrm{m}=1.37$, offset $\mathrm{b}=-44.1$, coefficient of determination $\mathrm{R}^{2}=0.85$. 


\section{$4 \mathrm{X}$-ray Crystal Structure Determinations}

Crystal data and details of the structure determinations are compiled in Table S3 and S4. Full shells of intensity data were collected at low temperature with an Agilent Technologies Supernova-E CCD diffractometer (Mo- or $\mathrm{Cu}-\mathrm{K}_{\alpha}$ radiation, microfocus $\mathrm{X}$-ray tube, multilayer mirror optics). Detector frames (typically $\omega$-, occasionally $\varphi$-scans, scan width $0.4 \ldots 1^{\circ}$ ) were integrated by profile fitting. ${ }^{24,25}$ Data were corrected for air and detector absorption, Lorentz and polarization effects ${ }^{24}$ and scaled essentially by application of appropriate spherical harmonic functions..$^{25,26,27}$ Absorption by the crystal was treated with a semiempirical multiscan method (as part of the scaling process) and augmented by a spherical correction, ${ }^{26,27}$ or numerically (Gaussian grid) ${ }^{26,28}$ An illumination correction was performed as part of the numerical absorption correction. ${ }^{26}$ The structures were solved by the charge flip procedure ${ }^{29}$ and refined by full-matrix least squares methods based on $\mathrm{F} 2$ against all unique reflections. ${ }^{30} \mathrm{All}$ non-hydrogen atoms were given anisotropic displacement parameters. Hydrogen atoms were input at calculated positions and refined with a riding model. Split atom models were used to refine disordered groups and/or solvent molecules. When found necessary, suitable geometry and adp restraints were applied. ${ }^{31}$

Crystals of $3^{\mathbf{t B u}}-\mathrm{Co}^{\mathrm{II}} \mathbf{H}$ were found to be twinned. The structure was solved using the nonoverlapping reflections of one domain after de-twinning; ${ }^{25}$ refinement was then carried out against all singles and composites of both domains. ${ }^{30}$ A difference Fourier synthesis with a model which did not include the hydride ligands indicated three maxima of electron density around each cobalt atom in the intensity range between 0.66 and $0.36 \mathrm{e} \cdot \AA^{-3}$. For only two of them (peak height $0.55 \mathrm{e} \cdot \AA^{-3}$ ) the distances to Co were in the range expected for hydride ligands $(1.3$... 1.4 $\mathrm{A})$. These maxima were assigned to the hydrides $\mathrm{H} 1$ and H51, which were then fully refined. Apart from the well-behaved refinement of the hydrides further evidence for the correct assignment of these peaks comes from a difference Fourier synthesis without the hydride ligands and with a resolution cutoff of $1.0 \AA$ (to reduce the contributions of the core Co atoms to the difference electron density), where the strongest peaks were indeed at the positions previously assigned to the hydride ligands. Hence, the residual electron density maxima close $(\leq 1 \AA)$ to the Co atoms, unaccounted for in the non-truncated Fourier map, can be attributed to the well known deficiencies of the ISA model employed, ${ }^{32}$ with a possible contribution of residual absorption effects.

CCDC 1882792 - 1882796 and 1895478 contains the supplementary crystallographic data for this paper. These data can be obtained free of charge from the Cambridge CrystallograhicData 
Centre's and FIZ Karlsruhe's joint Access Service via https://www.ccdc.cam.ac.uk/structures/?.

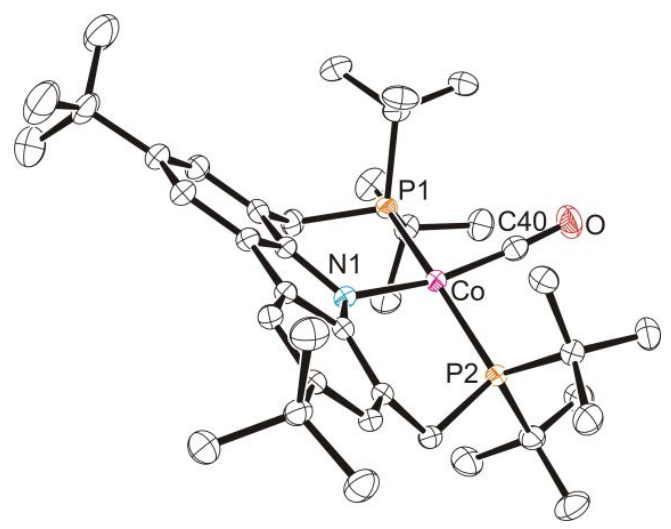

Figure S5: Molecular structure of $5^{\mathbf{t B u}}-\mathrm{Co}^{\mathrm{I}} \mathrm{CO}$. Hydrogen atoms have been omitted for clarity, displacement ellipsoids set at $50 \%$ probability. Selected bond lengths $[\AA]$ and angles [ ${ }^{\circ}$ : Co-N11.966(2)Co-P1 2.2315(7) Co-P22.2363(7) Co-C401.684(3) C40-O1.174(3) P1-Co-P2 164.36(3) N1-Co-P1 94.38(6) N1-Co-P2 94.22(6) C40-Co-P1 87.74(9) C40Co-P2 88.17(9) C40-Co-N1 161.74(12).

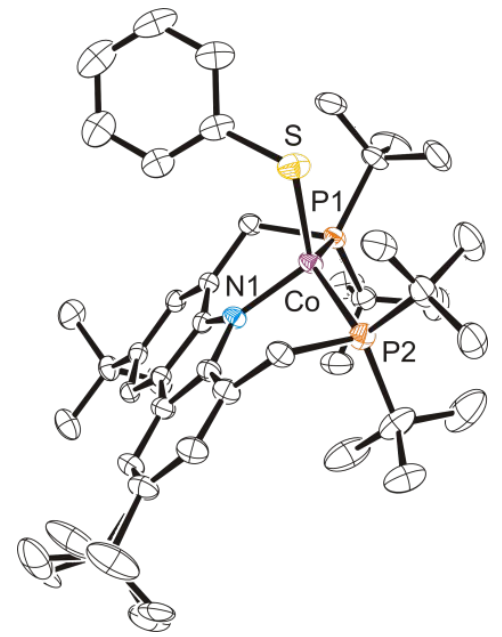

Figure S6: Molecular structure of $7^{\mathbf{t B u}}-\mathrm{Co}^{\mathrm{II}} \mathrm{SPh}$. Hydrogen atoms have been omitted for clarity, displacement ellipsoids set at $50 \%$ probability. Selected bond lengths $[\AA]$ and angles [ ${ }^{\circ}$ ]: Co-N11.920(2) Co-S2.2585(8) Co-P1 2.4126(8) Co-P22.4086(8) P1-Co-P2 134.84(3) N1-Co-P1 97.48(7) N1-Co-P2 95.87(7) S-Co-P1 111.79(3) S-Co-P2 100.01(3) S-Co-N1 116.53(7). 
Table S3: Details of the crystal structure determinations of $3^{\text {iPr }}-{ }_{-}{ }^{\mathrm{II}} \mathbf{H}$.

\begin{tabular}{|c|c|c|c|}
\hline & $3^{i \mathrm{Pr}}-\mathrm{Co}^{\mathrm{II}} \mathrm{H}$ & & \\
\hline formula & C34H55CoNP2 & X-radiation, $\lambda / \AA$ & Mo K $_{\alpha}, 0.71073$ \\
\hline crystal system & monoclinic & data collect. temperat. /K & $120(1)$ \\
\hline space group & P 21/c & $\theta$ range $/^{\circ}$ & 2.3 to 26.4 \\
\hline $\mathrm{a} / \AA$ & $12.4557(5)$ & index ranges $h, k, l$ & $-15 \ldots 15,-27 \ldots 27,-30 \ldots 30$ \\
\hline $\mathrm{b} / \AA$ & $22.2416(4)$ & reflections measured & 247395 \\
\hline$c / \AA$ & $24.5058(3)$ & unique [Rint] & $25493[0.0737]$ \\
\hline$\beta /{ }^{\circ}$ & $91.994(2)$ & observed $[I \geq 2 \sigma(I)]$ & 16784 \\
\hline $\mathrm{V} / \AA^{3}$ & $6784.9(3)$ & data / restraints / parameters & 25493 / 300 / 747 \\
\hline Z & 8 & GooF on $\mathrm{F}^{2}$ & 0.874 \\
\hline $\mathrm{M}_{\mathrm{r}}$ & 598.66 & $R$ indices $[F>4 \sigma(F)] R(F), w R\left(F^{2}\right)$ & $0.0368,0.0739$ \\
\hline $\mathrm{F}_{000}$ & 2584 & $\mathrm{R}$ indices (all data) $\mathrm{R}(\mathrm{F}), \mathrm{wR}\left(\mathrm{F}^{2}\right)$ & $0.0610,0.0767$ \\
\hline $\mathrm{d}_{\mathrm{c}} / \mathrm{Mg} \cdot \mathrm{m}^{-3}$ & 1.172 & absolute structure parameter & \\
\hline $\begin{array}{l}\mu / \mathrm{mm}^{-1} \\
\text { max., min. trans- }\end{array}$ & 0.622 & largest residual peaks $/ \mathrm{e} \cdot \AA^{-3}$ & $0.054,0.644,-0.387$ \\
\hline mission factors & $1.000,0.672^{\mathrm{a}}$ & CCDC deposition number & 1895478 \\
\hline
\end{tabular}

a numerical absorption correction. 
Table S4: Details of the crystal structure determinations of $2^{i \mathrm{Pr}}-\mathrm{Co}^{\mathrm{II}} \mathbf{C l}, 2^{\mathrm{tBu}}-\mathrm{Co}^{\mathrm{II}} \mathrm{Cl} \cdot 0.5 \mathrm{n}$ pentane, $4^{\mathrm{tBu}}-\mathrm{Co}^{\mathrm{I}}, 5^{\mathrm{tBu}}-\mathrm{Co}^{\mathrm{I}} \mathrm{CO}$ and $7^{\mathrm{tBu}}-\mathrm{Co}^{\mathrm{II}} \mathrm{SPh}$

\begin{tabular}{|c|c|c|c|c|c|}
\hline & $2^{\mathrm{i} p_{r}-\mathrm{CoCl}}$ & $2^{2^{1 B u}-C o C l} \square 0.5 n$-pentane & $4^{\mathrm{E} B u_{-} C o^{I}}$ & $5^{\mathrm{tBu}-\mathrm{CoCO}}$ & $7^{\mathrm{tBu}-\mathrm{CoSPh}}$ \\
\hline formula & $\mathrm{C}_{34} \mathrm{H}_{54} \mathrm{ClCoNP}_{2}$ & $\mathrm{C}_{40.50} \mathrm{H}_{68} \mathrm{ClCoNP}_{2}$ & $\mathrm{C}_{38} \mathrm{H}_{62} \mathrm{CoNP}_{2}$ & $\mathrm{C}_{39} \mathrm{H}_{62} \mathrm{CoNOP}_{2}$ & $\mathrm{C}_{44} \mathrm{H}_{67} \mathrm{CoNP}_{2} \mathrm{~S}$ \\
\hline crystal system & orthorhombic & monoclinic & orthorhombic & orthorhombic & tetragonal \\
\hline space group & $P 2_{1} 2_{1} 2_{1}$ & $P 2{ }_{1} / n$ & $P 2{ }_{1}{ }_{1} 2$ & $P b c a$ & $I-4$ \\
\hline$a / \AA$ & $12.94513(13)$ & $22.9848(4)$ & $17.2696(2)$ & $23.52553(18)$ & $23.84662(11)$ \\
\hline$b / \AA$ & $21.7920(2)$ & $14.5816(3)$ & $17.2023(2)$ & $12.05356(10)$ & \\
\hline$c / \AA$ & $25.1085(2)$ & $24.7241(5)$ & $13.04203(15)$ & $26.9602(3)$ & $15.19295(8)$ \\
\hline$\beta /^{\circ}$ & & $94.0085(16)$ & & & \\
\hline$V / \AA^{3}$ & $7083.09(12)$ & $8266.1(3)$ & $3874.48(8)$ & $7645.01(11)$ & $8639.64(10)$ \\
\hline$Z$ & 8 & 8 & 4 & 8 & 8 \\
\hline$M_{\mathrm{r}}$ & 633.10 & 725.27 & 653.75 & 681.76 & 762.91 \\
\hline$F_{000}$ & 2712 & 3136 & 1416 & 2944 & 3288 \\
\hline$d_{\mathrm{c}} / \mathrm{Mg} \cdot \mathrm{m}^{-3}$ & 1.187 & 1.166 & 1.121 & 1.185 & 1.173 \\
\hline$\mu / \mathrm{mm}^{-1}$ & 0.672 & 4.767 & 0.550 & 4.519 & 4.473 \\
\hline $\begin{array}{l}\text { max., min. transmission } \\
\text { factors }\end{array}$ & $1.000,0.710^{\mathrm{a}}$ & $1.000,0.565^{\text {a }}$ & $1.000,0.770^{\mathrm{a}}$ & $0.7842,0.7736^{\mathrm{b}}$ & $1.0000,0.6963^{\mathrm{b}}$ \\
\hline $\mathrm{X}$-radiation, $\lambda / \AA$ & Mo- $K \alpha, 0.71073$ & $\mathrm{Cu}-K \alpha, 1.54184$ & Mo- $K \alpha, 0.71073$ & $\mathrm{Cu}-K \alpha, 1.54184$ & $\mathrm{Cu}-K \alpha, 1.54184$ \\
\hline data collect. temperat. /K & $120(1)$ & $120(1)$ & $120(1)$ & $120(1)$ & $120(1)$ \\
\hline$\theta$ range $/^{\circ}$ & 2.3 to 32.4 & 2.7 to 67.4 & 2.3 to 32.4 & 3.3 to 70.9 & 3.4 to 71.4 \\
\hline
\end{tabular}

\begin{tabular}{|c|c|c|c|c|c|}
\hline & $2^{\mathrm{iPr}-}-\mathrm{CoCl}$ & $2^{\mathrm{t} B u}$ - $C o C l \square 0.5 n$-pentane & $4^{\mathrm{t} B u_{-} C O^{I}}$ & 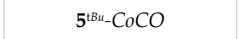 & $7^{\text {tBu-}}-C o S P h$ \\
\hline index ranges $h, k, l$ & $\begin{array}{c}-19 \ldots 19,-32 \ldots 31,-37 \\
\ldots 37\end{array}$ & $\begin{array}{c}-27 \ldots 27,-17 \ldots 17,-29 \ldots \\
29\end{array}$ & $-25 \ldots 25,-25 \ldots 25,-19 \ldots 19$ & $-28 \ldots 28,-14 \ldots 14,-32 \ldots$ & $\begin{array}{c}-29 \ldots 29,-29 \ldots 28,-18 \ldots \\
18\end{array}$ \\
\hline reflections measured & 212770 & 225631 & 117799 & 263427 & 189110 \\
\hline unique $\left[R_{\text {int }}\right]$ & $24635[0.0636]$ & $14818[0.1097]$ & $13534[0.0700]$ & $7374[0.0857]$ & $8356[0.0606]$ \\
\hline$[I \geq 2 \sigma(I)]{ }^{\text {observed }}$ & 21513 & 11278 & 11777 & 6544 & 7969 \\
\hline data / restraints /parameters & $24635 / 159 / 731$ & $14818 / 1107 / 849$ & $13534 / 168 / 447$ & $7374 / 0 / 415$ & $8356 / 73 / 494$ \\
\hline GooF on $F^{2}$ & 1.032 & 1.018 & 1.041 & 1.088 & 1.018 \\
\hline $\begin{array}{l}R \text { indices }[F>4 \sigma(F)] R(F), \\
w R\left(F^{2}\right)\end{array}$ & $0.0373,0.0789$ & $0.0512,0.1175$ & $0.0403,0.0868$ & $0.0478,0.1097$ & $0.0281,0.0637$ \\
\hline $\begin{array}{l}R \text { indices (all data) } R(F), \\
w R\left(F^{2}\right)\end{array}$ & $0.0483,0.0831$ & $0.0745,0.1294$ & $0.0518,0.0918$ & $0.0562,0.1141$ & $0.0307,0.0649$ \\
\hline $\begin{array}{l}\text { absolute structure } \\
\text { parameter }\end{array}$ & $-0.002(3)$ & & $0.012(4)$ & & $-0.0249(14)$ \\
\hline largest residual peaks $/ \mathrm{e} \cdot \AA^{-3}$ & $0.500,-0.336$ & $0.929,-0.702$ & $0.730,-0.265$ & $1.057,-0.498$ & $0.233,-0.196$ \\
\hline CCDC deposition number & 1882792 & 1882793 & 1882794 & 1882795 & 1882796 \\
\hline
\end{tabular}

${ }^{a}$ numerical absorption correction. ${ }^{\mathrm{b}}$ semi-empirical absorption correction. 


\section{NMR Spectra}

${ }^{1} \mathrm{H}$ NMR spectrum $\left(\mathrm{C}_{6} \mathrm{D}_{6}, 600.15 \mathrm{MHz}, 293 \mathrm{~K}\right)$

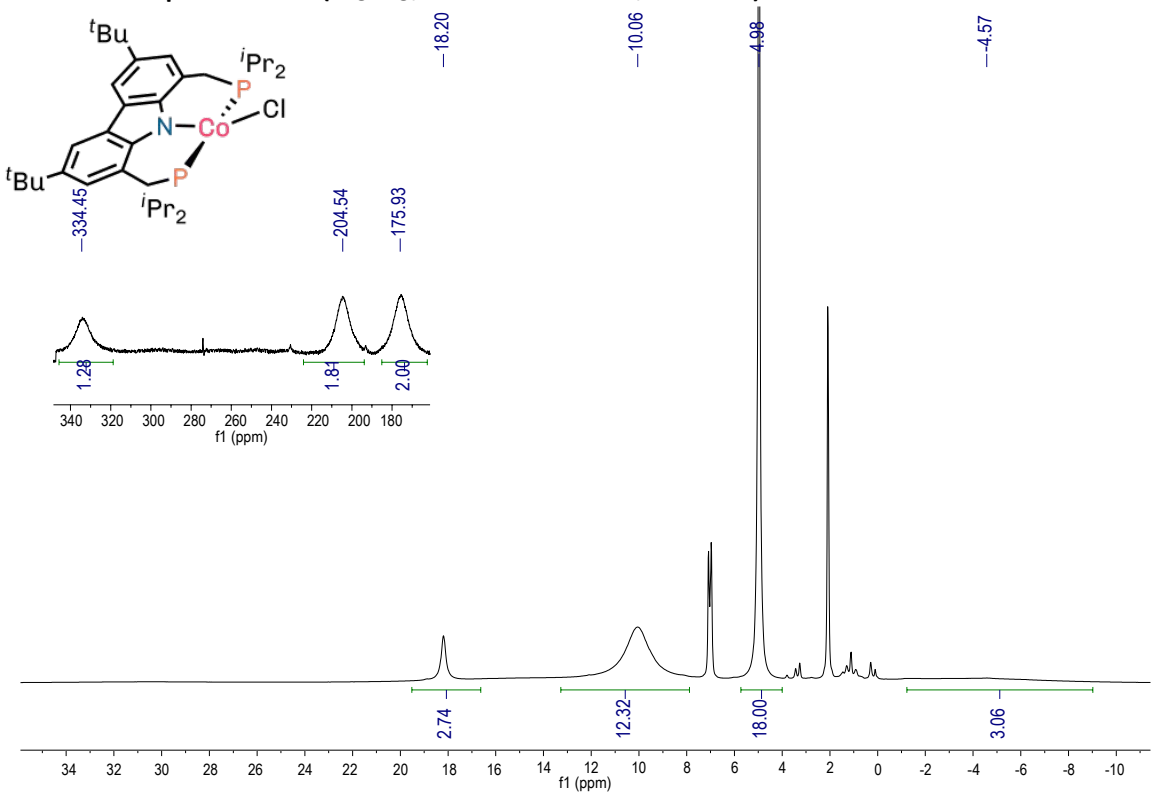

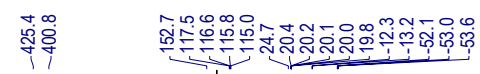

${ }^{13} \mathrm{C}$ NMR spectrum (toluene- $\mathrm{d}_{8}, 150.90 \mathrm{MHz}, 293 \mathrm{~K}$ )
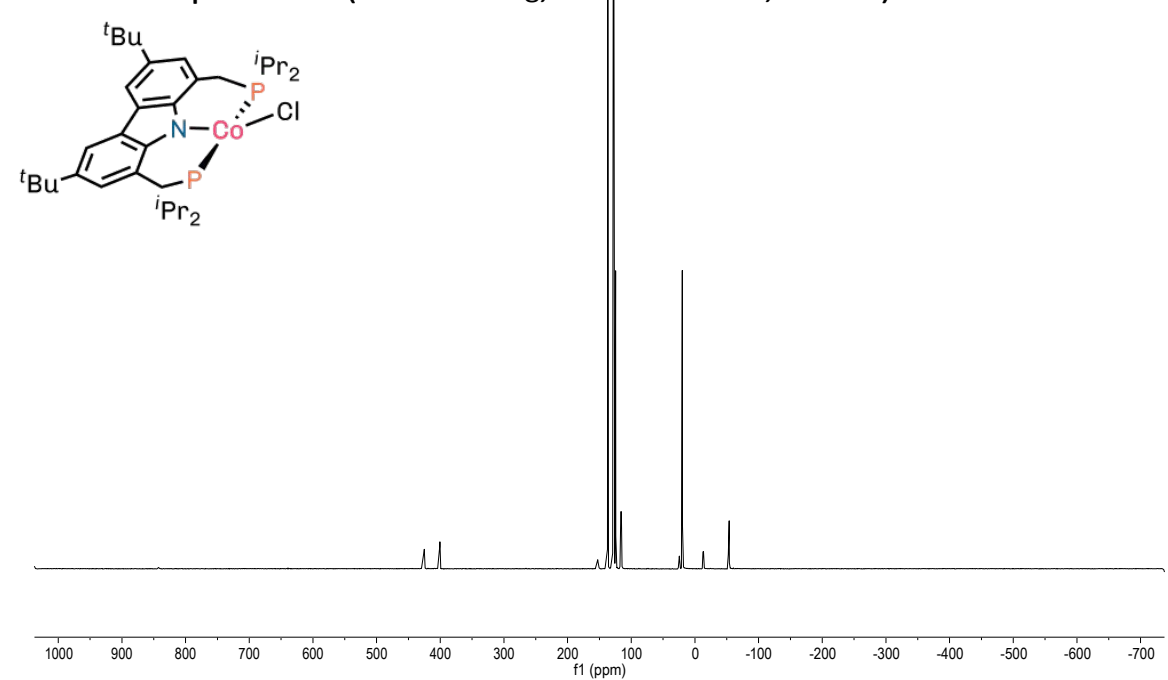
${ }^{1}$ H NMR spectrum $\left(C_{6} D_{6}, 600.15 \mathrm{MHz}, 293 \mathrm{~K}\right)$

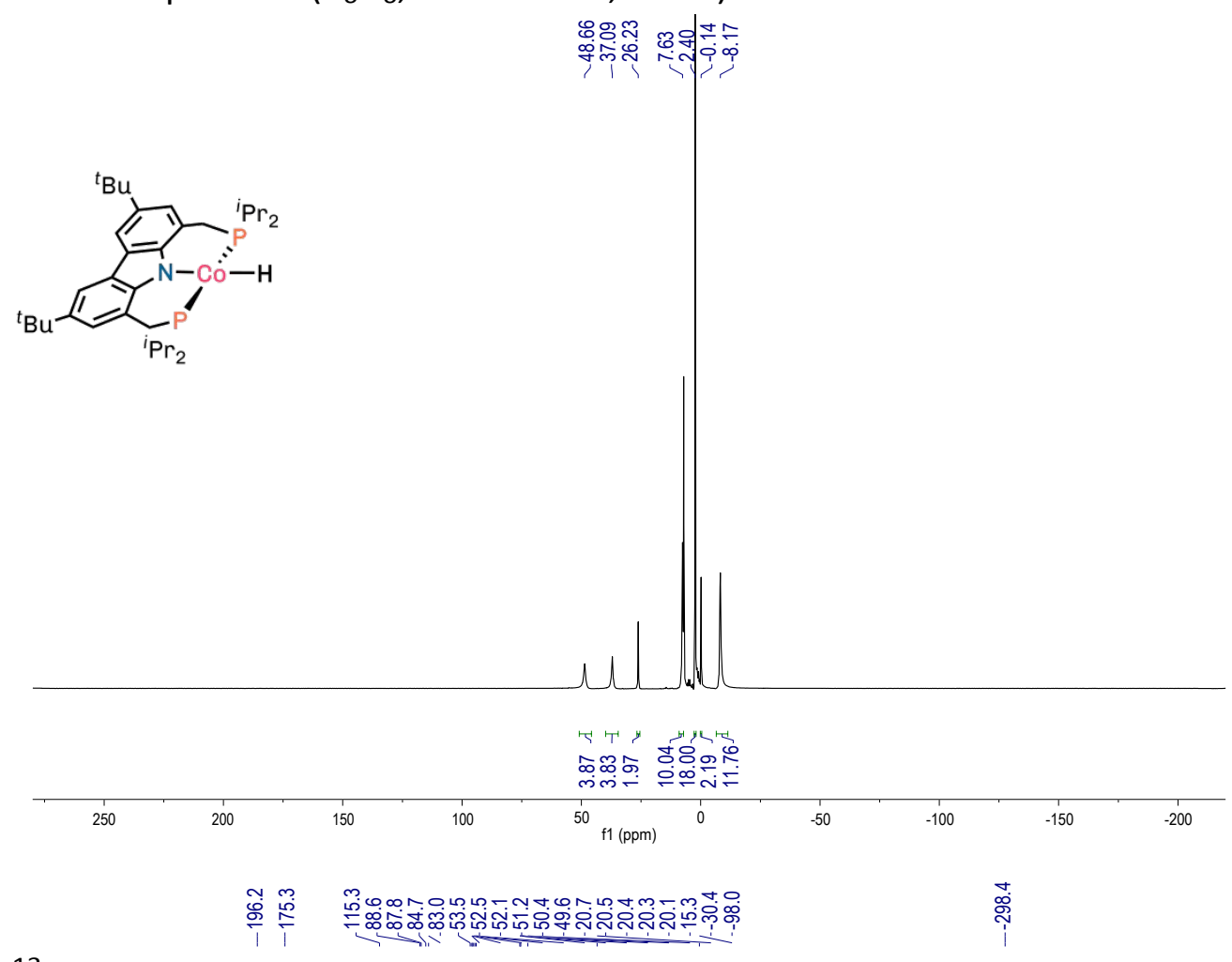

${ }^{13} \mathrm{C}$ NMR spectrum ( $\left.\mathrm{C}_{6} \mathrm{D}_{6}, 150.90 \mathrm{MHz}, 293 \mathrm{~K}\right)$
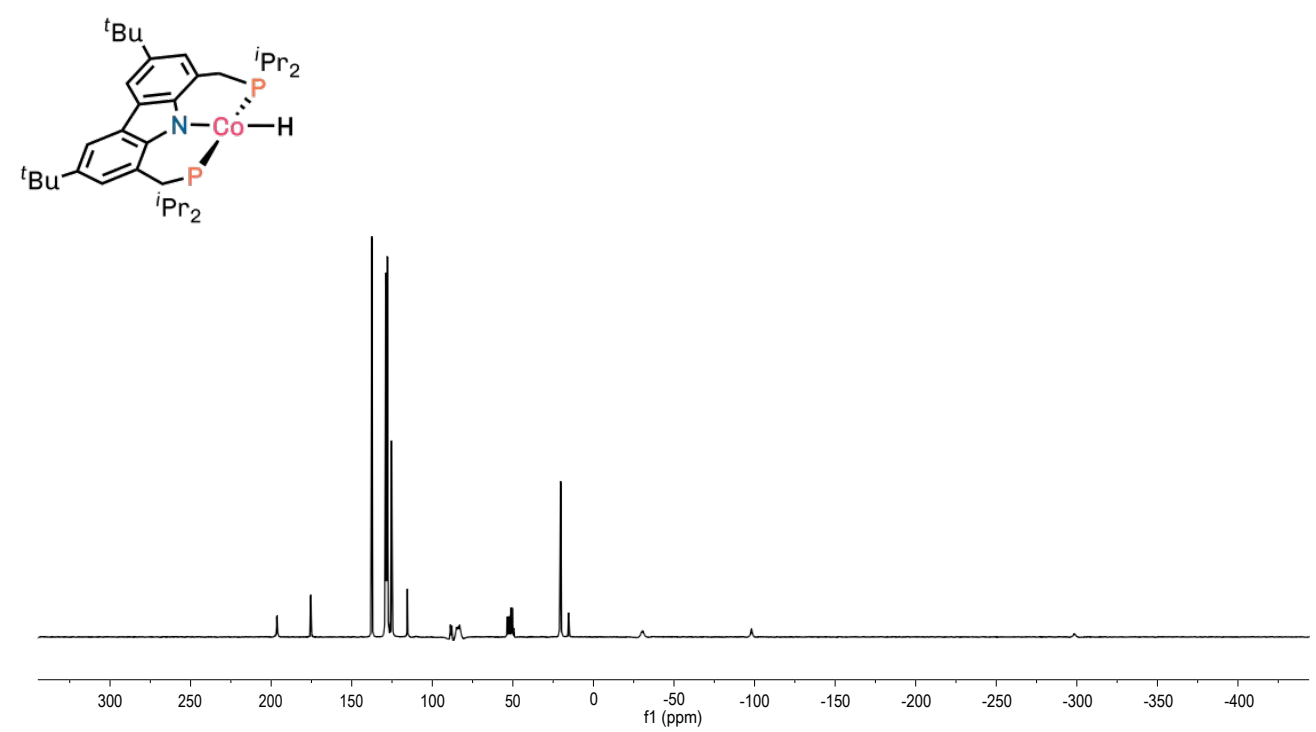
${ }^{1} \mathrm{H}$ NMR spectrum $\left(\mathrm{C}_{6} \mathrm{D}_{6}, 600.15 \mathrm{MHz}, 233 \mathrm{~K}\right)$

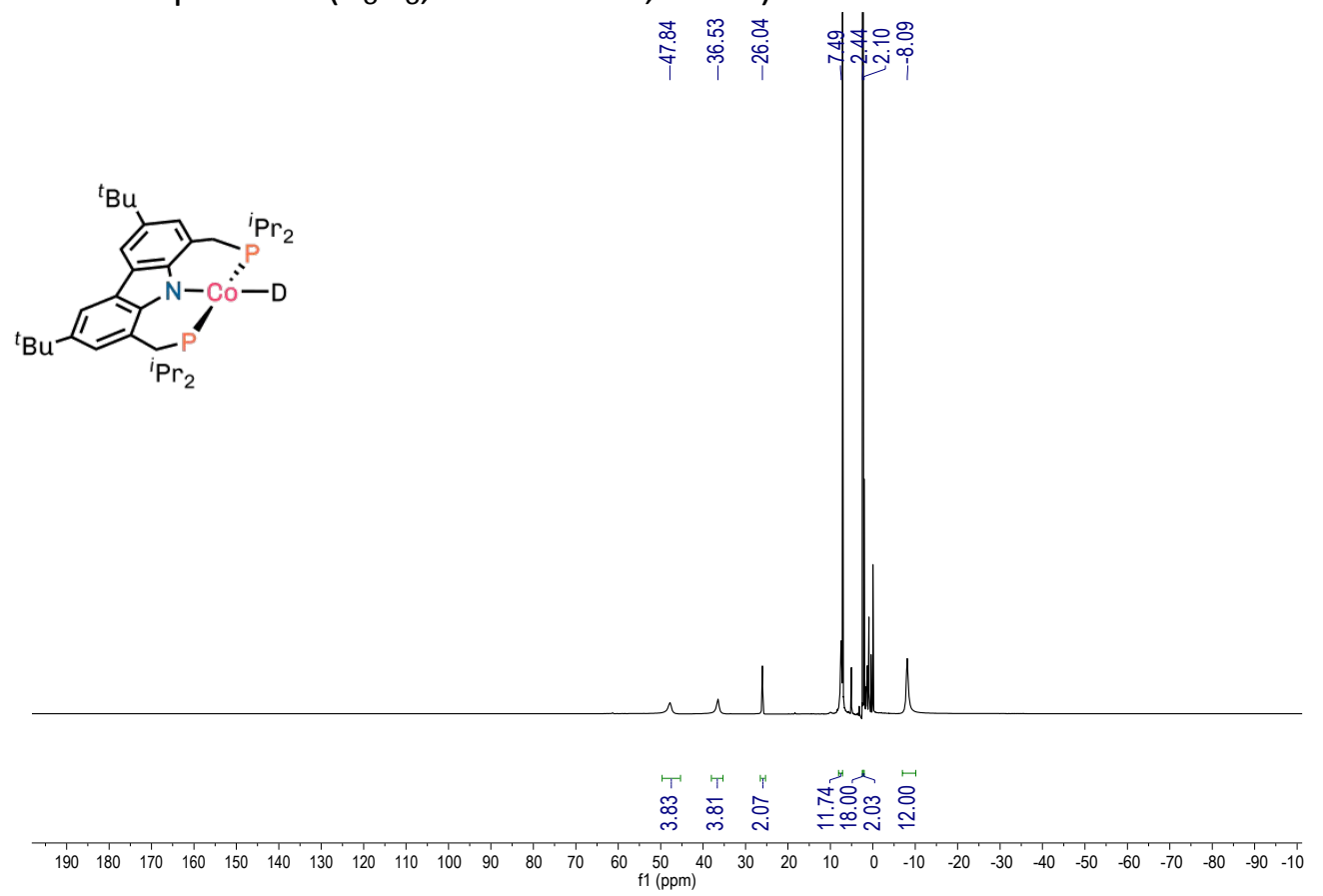


${ }^{1} \mathrm{H}$ NMR spectrum $\left(\mathrm{C}_{6} \mathrm{D}_{6}, 600.15 \mathrm{MHz}, 293 \mathrm{~K}\right)$
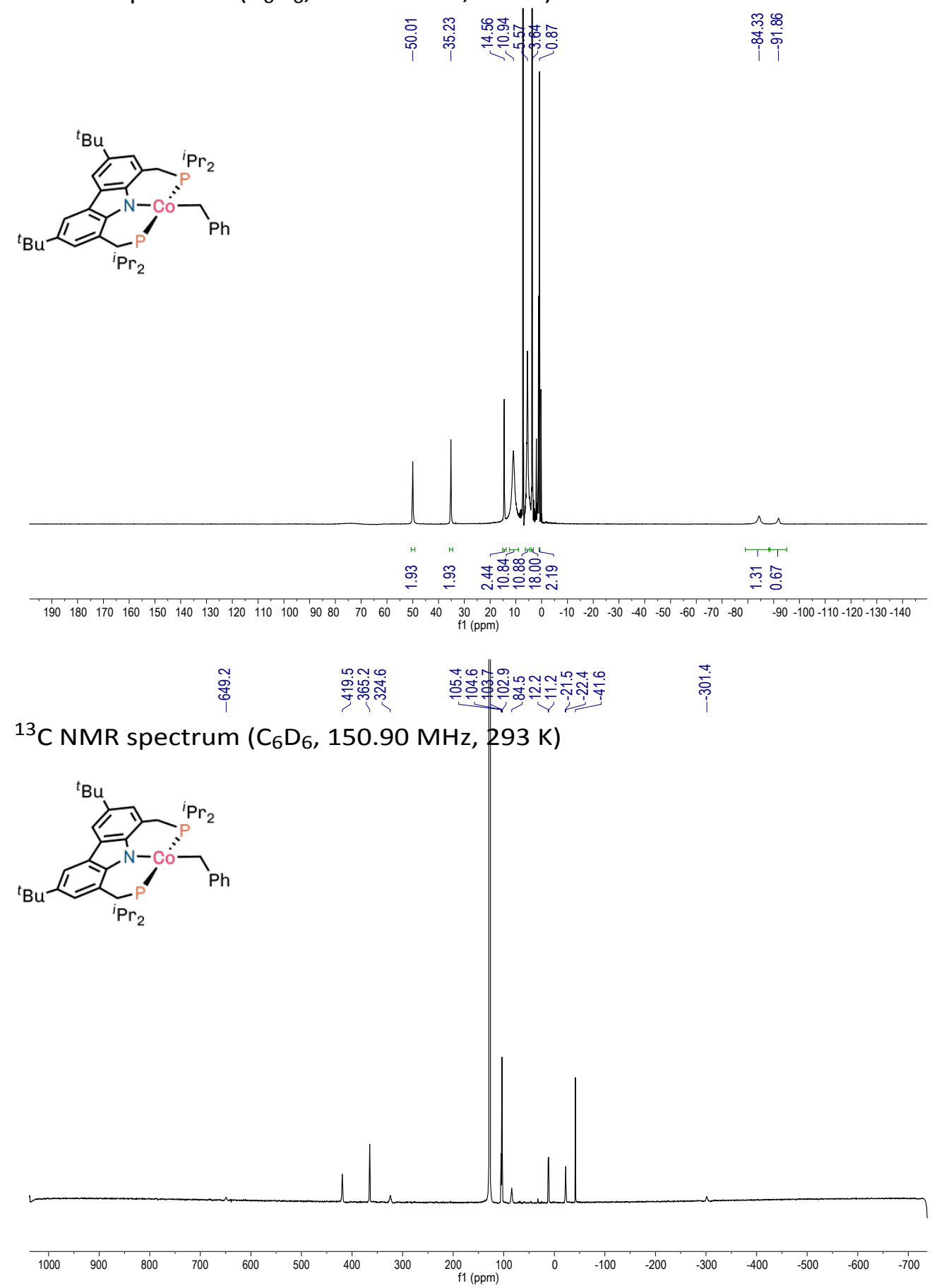
${ }^{1} \mathrm{H}$ NMR spectrum $\left(\mathrm{C}_{6} \mathrm{D}_{6}, 600.15 \mathrm{MHz}, 293 \mathrm{~K}\right)$

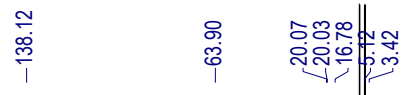

(l)

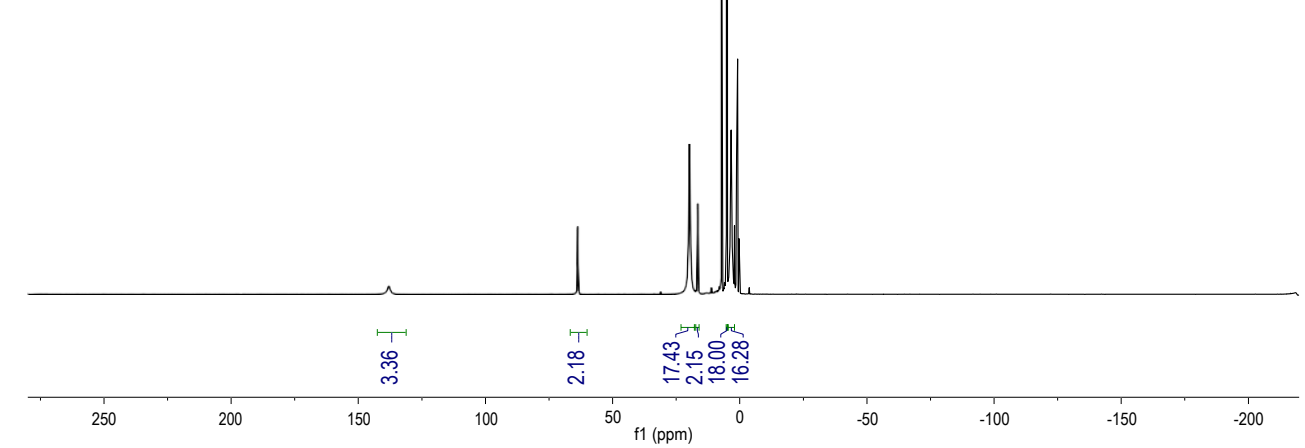

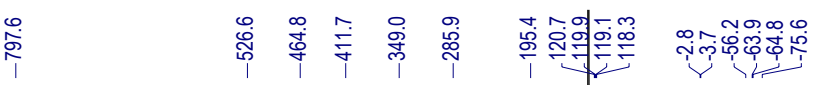

${ }^{13} \mathrm{C}$ NMR spectrum $\left(\mathrm{C}_{6} \mathrm{D}_{6}, 150.90 \mathrm{MHz}, 293 \mathrm{~K}\right)$

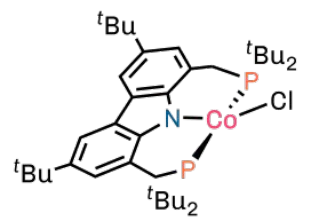

${ }^{\mathrm{t}} \mathrm{Bu}_{2}$

$\begin{array}{lllllllllllllllllllllllllllllllllllll}850 & 800 & 750 & 700 & 650 & 600 & 550 & 500 & 450 & 400 & 350 & 300 & 250 & 200 & 150 & 100 & 50 & 0 & -50 & -10 & -150 & -200 & -250 & -300 & -350 & -400 & -450 & -500 & -550 & \end{array}$ 
${ }^{1} \mathrm{H}$ NMR spectrum $\left(\mathrm{C}_{6} \mathrm{D}_{6}, 600.15 \mathrm{MHz}, 293 \mathrm{~K}\right)$

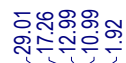

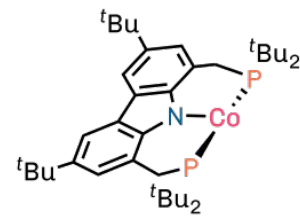

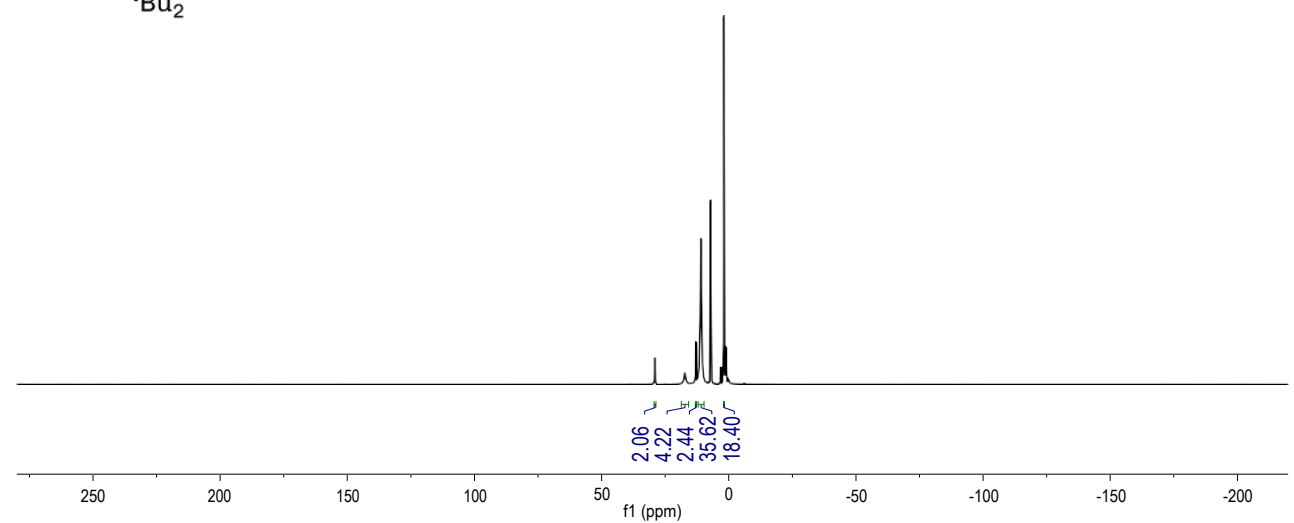

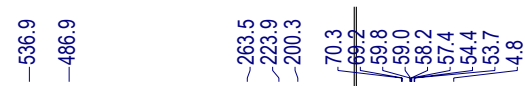

$\stackrel{\text { ị }}{i}$

${ }^{13} \mathrm{C}$ NMR spectrum $\left(\mathrm{C}_{6} \mathrm{D}_{6}, 150.90 \mathrm{MHz}, 293 \mathrm{~K}\right)$

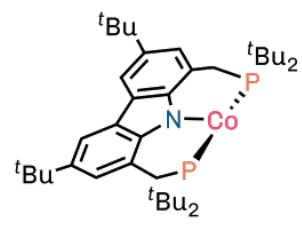

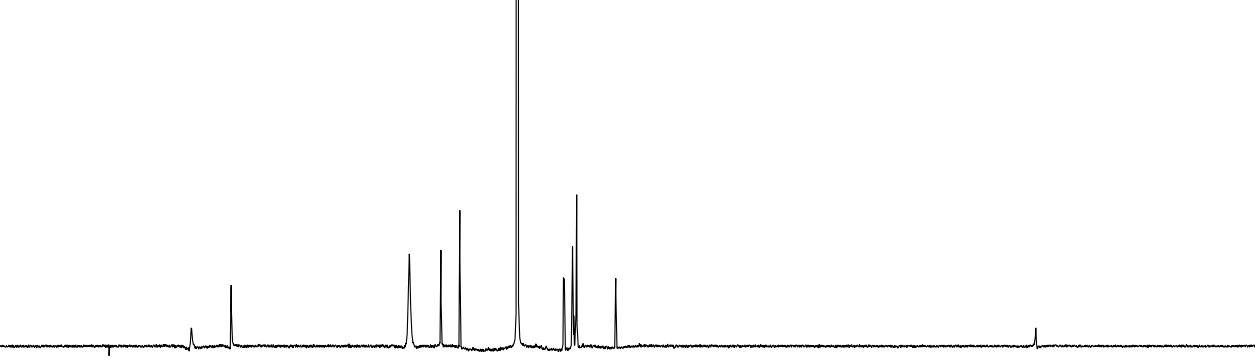

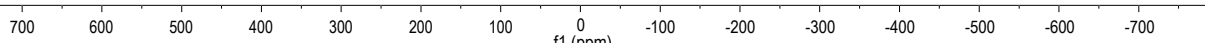


${ }^{1} \mathrm{H}$ NMR spectrum $\left(\mathrm{C}_{6} \mathrm{D}_{6}, 600.15 \mathrm{MHz}, 293 \mathrm{~K}\right)$

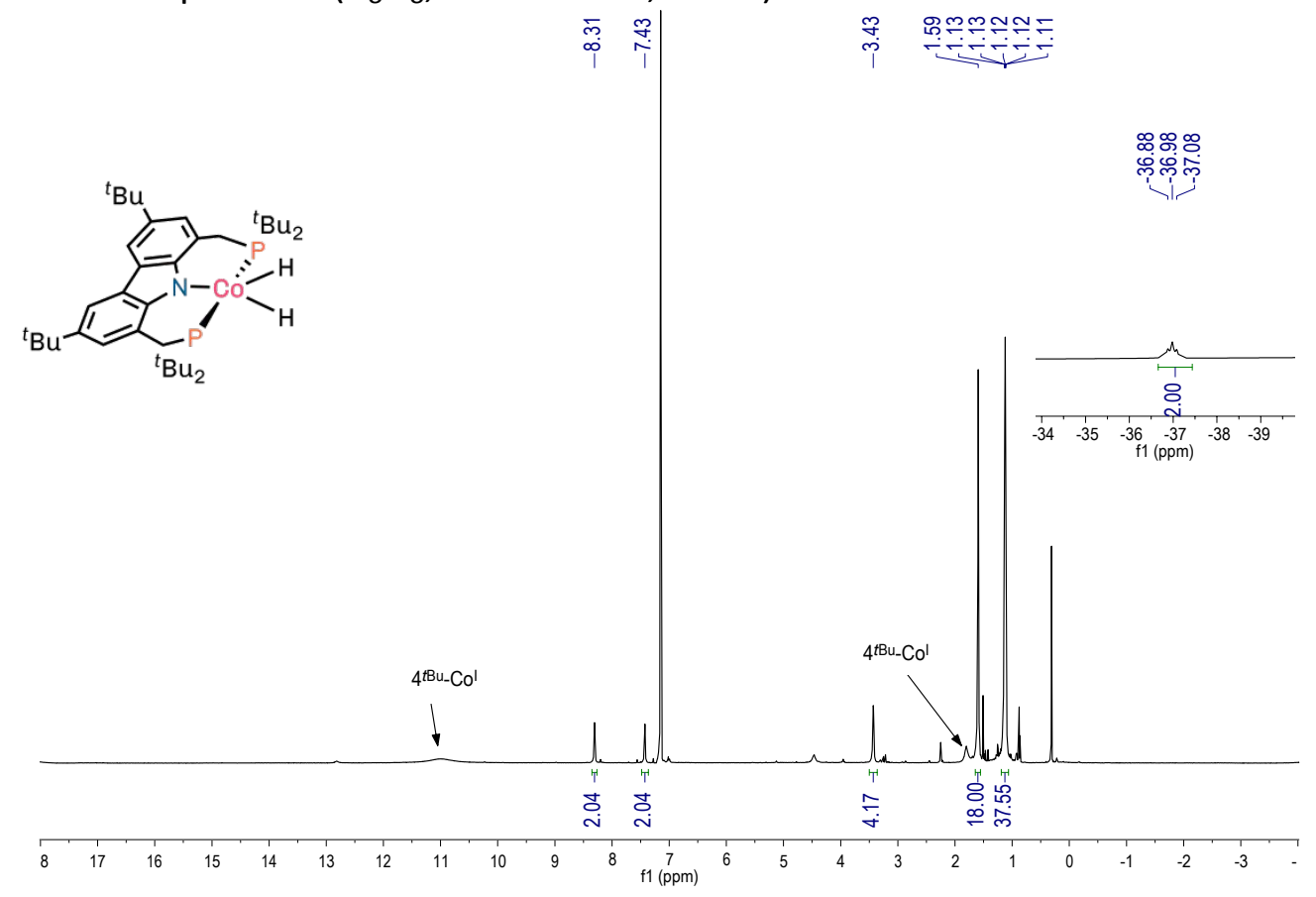

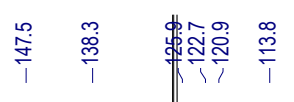

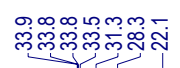

${ }^{13} \mathrm{C}$ NMR spectrum $\left(\mathrm{C}_{6} \mathrm{D}_{6}, 150.90 \mathrm{MHz}, 293 \mathrm{~K}\right)$

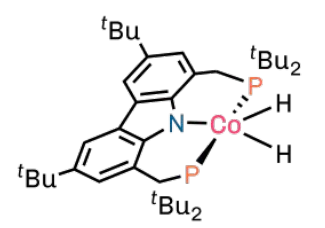

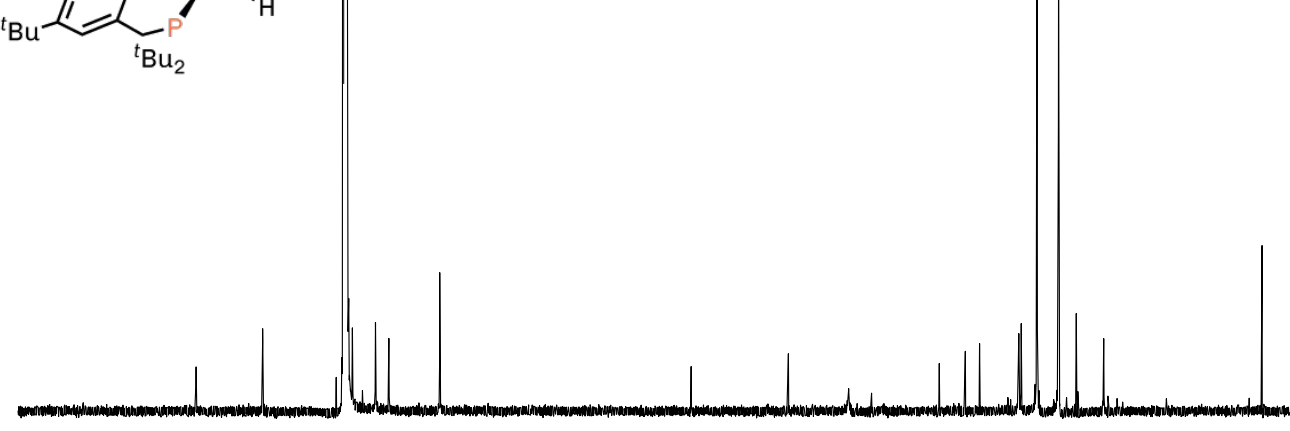

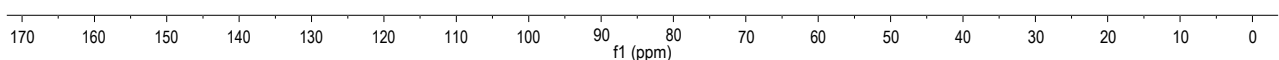


${ }^{1} \mathrm{H}$ NMR spectrum $\left(\mathrm{C}_{6} \mathrm{D}_{6}, 600.15 \mathrm{MHz}, 293 \mathrm{~K}\right)$

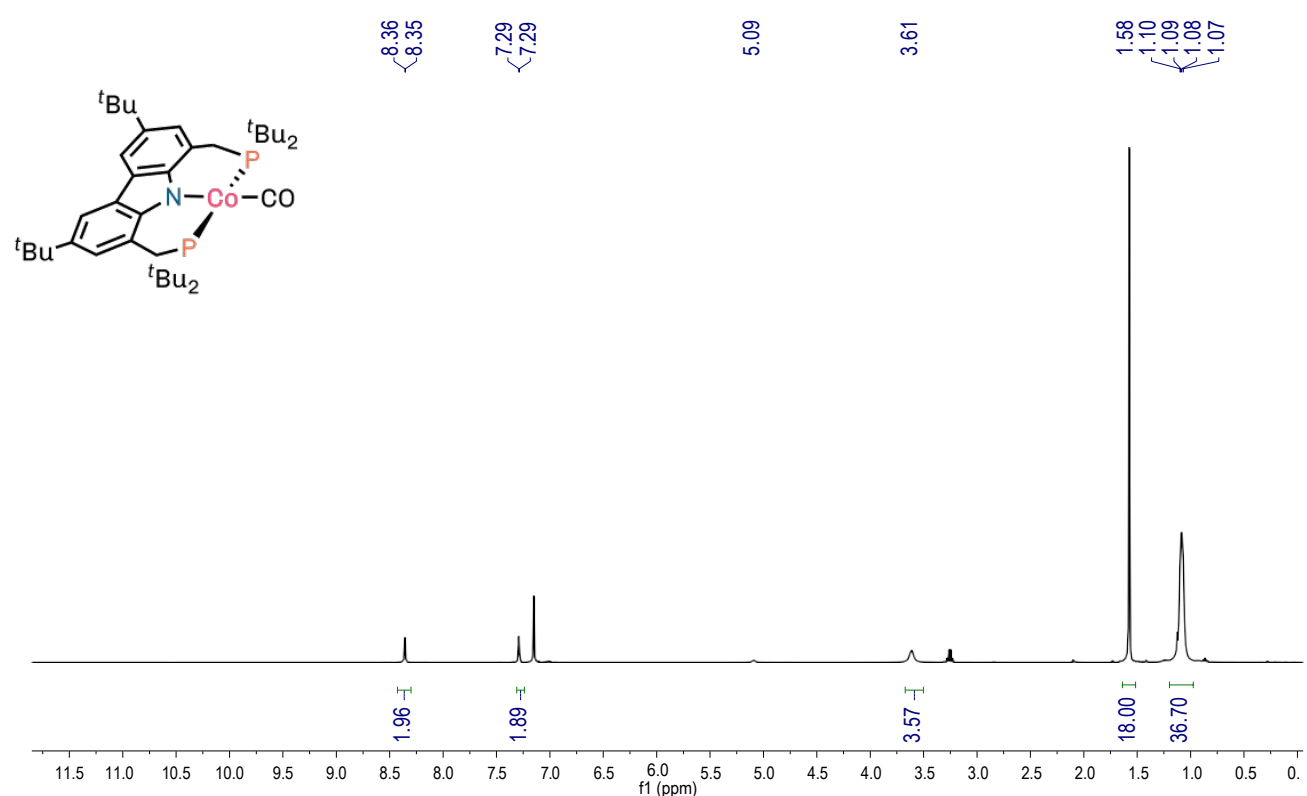

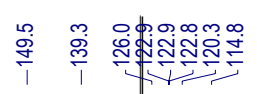

${ }^{13} \mathrm{C}$ NMR spectrum $\left(\mathrm{C}_{6} \mathrm{D}_{6}, 15090 \mathrm{MHz}, 293 \mathrm{~K}\right)$

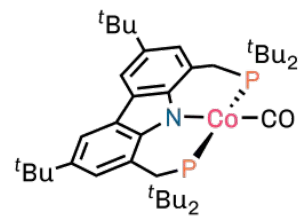

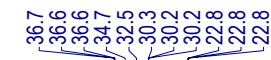

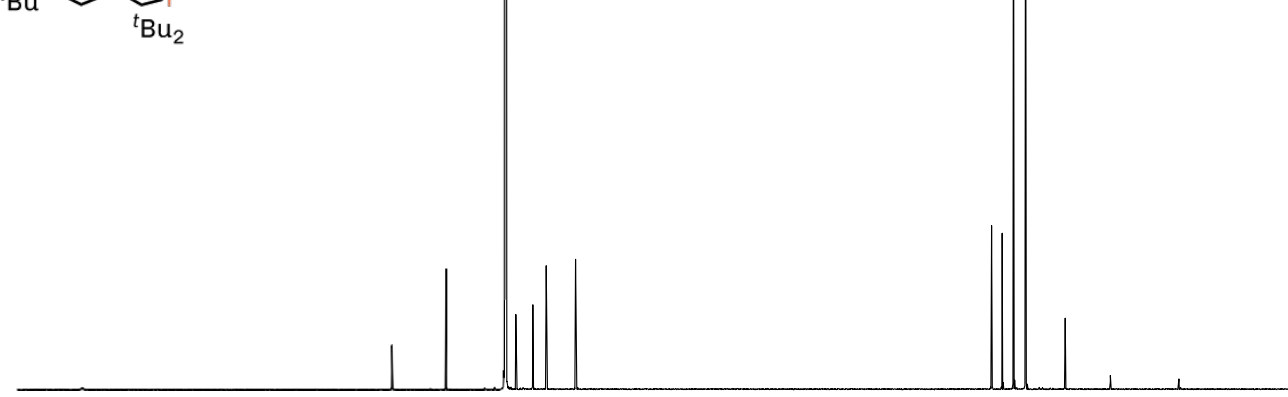

$\begin{array}{llllllllllllllllllllllllllll}1 & 210 & 200 & 190 & 180 & 170 & 160 & 150 & 140 & 130 & 120 & 110 & 100 & 90 & 80 & 70 & 60 & 50 & 40 & 30 & 20 & 10 & 0 & -10\end{array}$ 
${ }^{31} \mathrm{P}$ NMR spectrum $\left(\mathrm{C}_{6} \mathrm{D}_{6}, 242.94 \mathrm{MHz}, 293 \mathrm{~K}\right)$

$\stackrel{8}{\circ}$

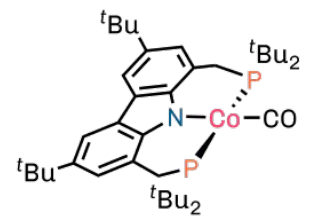

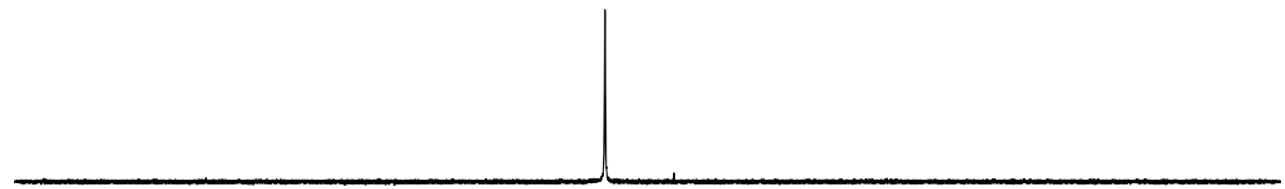

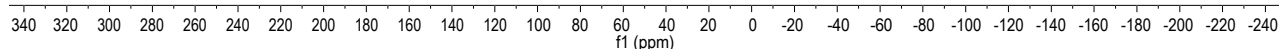



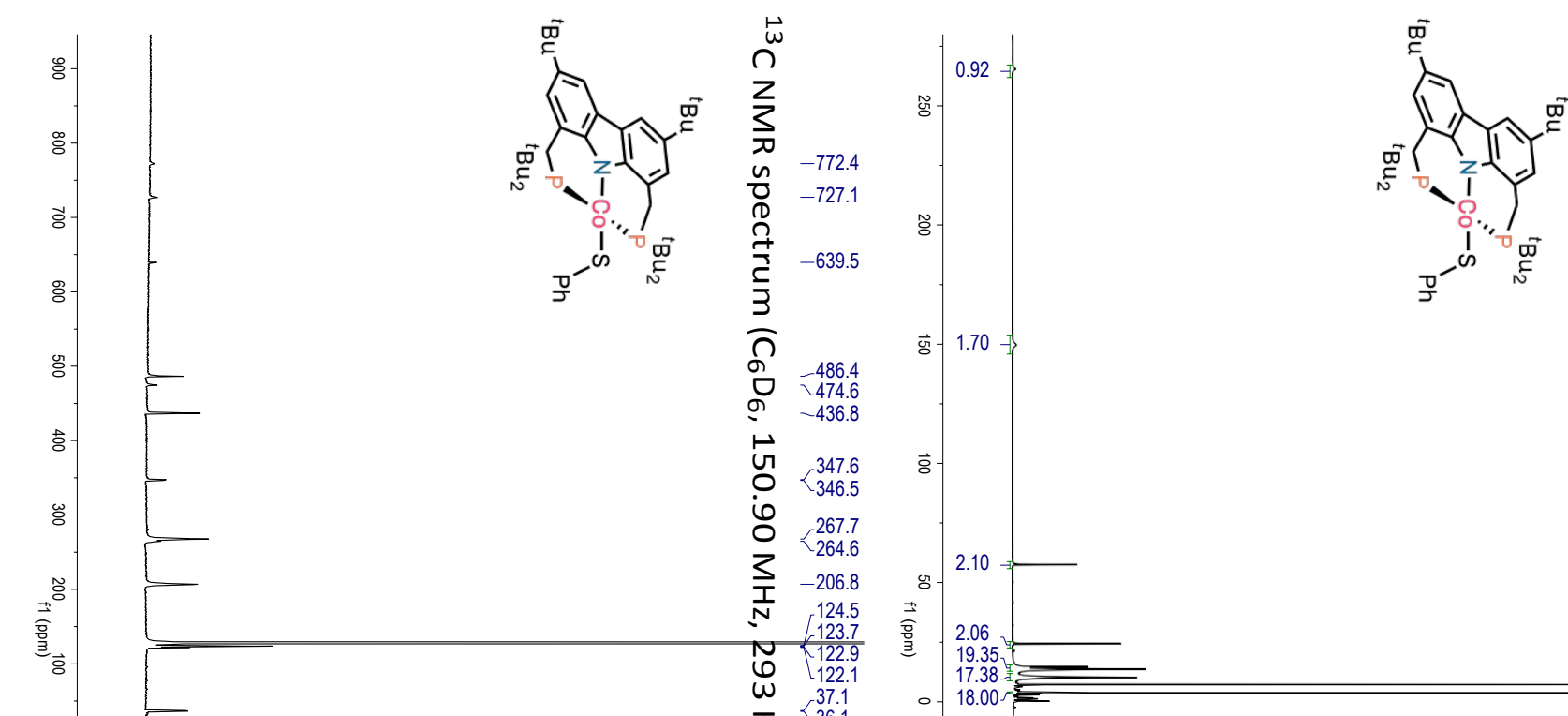

$-265.36 \stackrel{\text { 殅 }}{\underline{3}}$

त

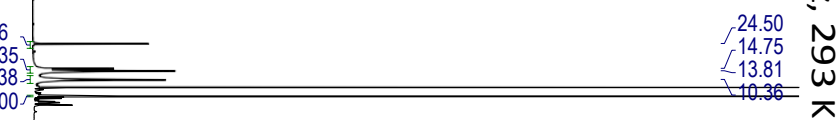
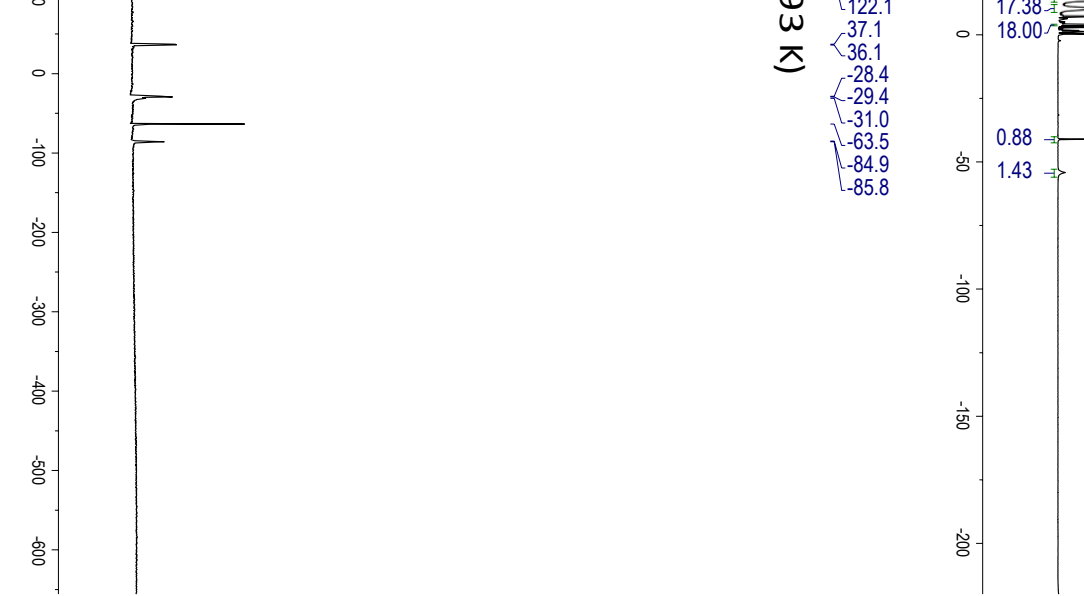


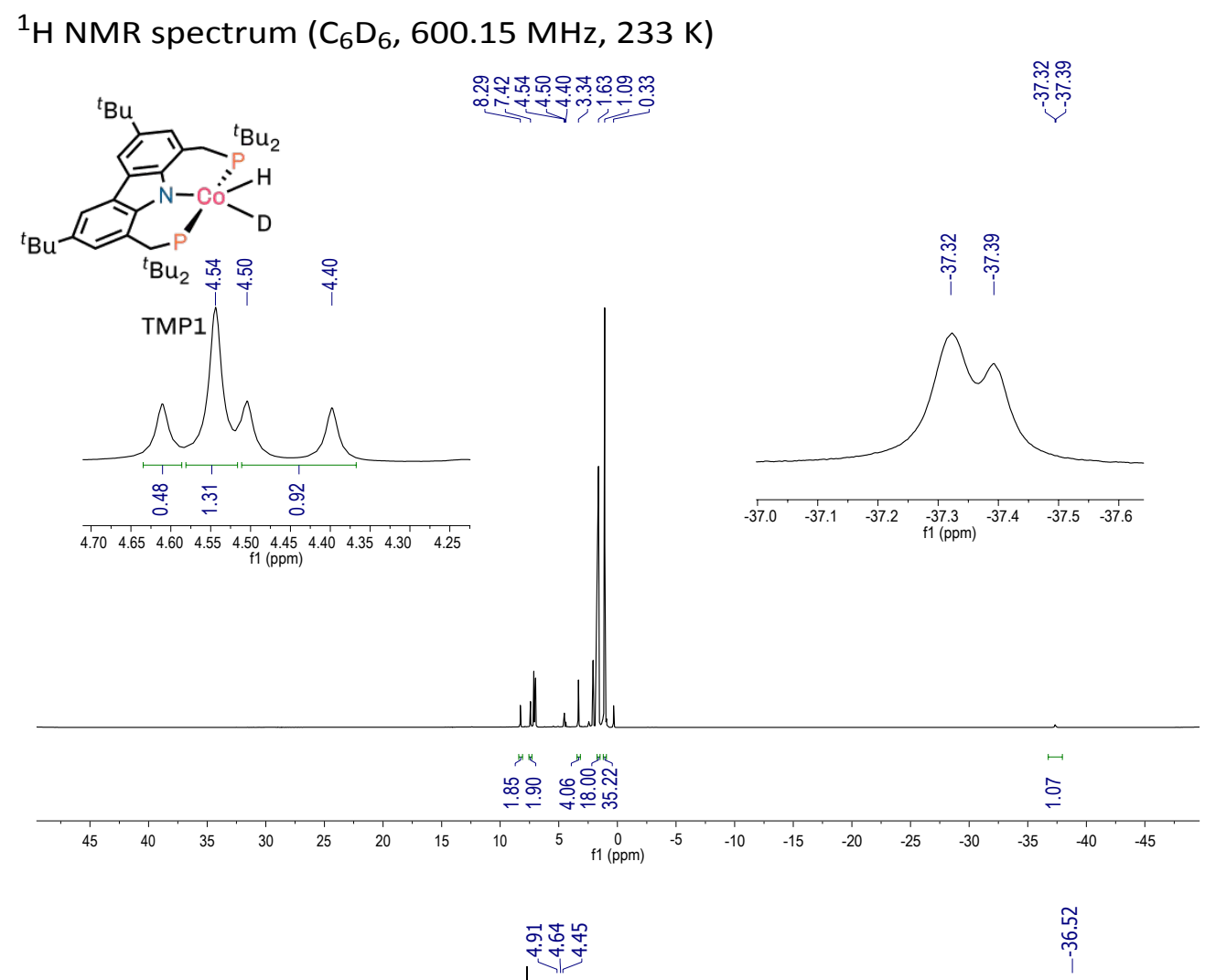

${ }^{2} \mathrm{H}$ NMR spectrum (toluene- $\mathrm{d}_{8}, 92.12 \mathrm{MHz}, 293 \mathrm{~K}$ )

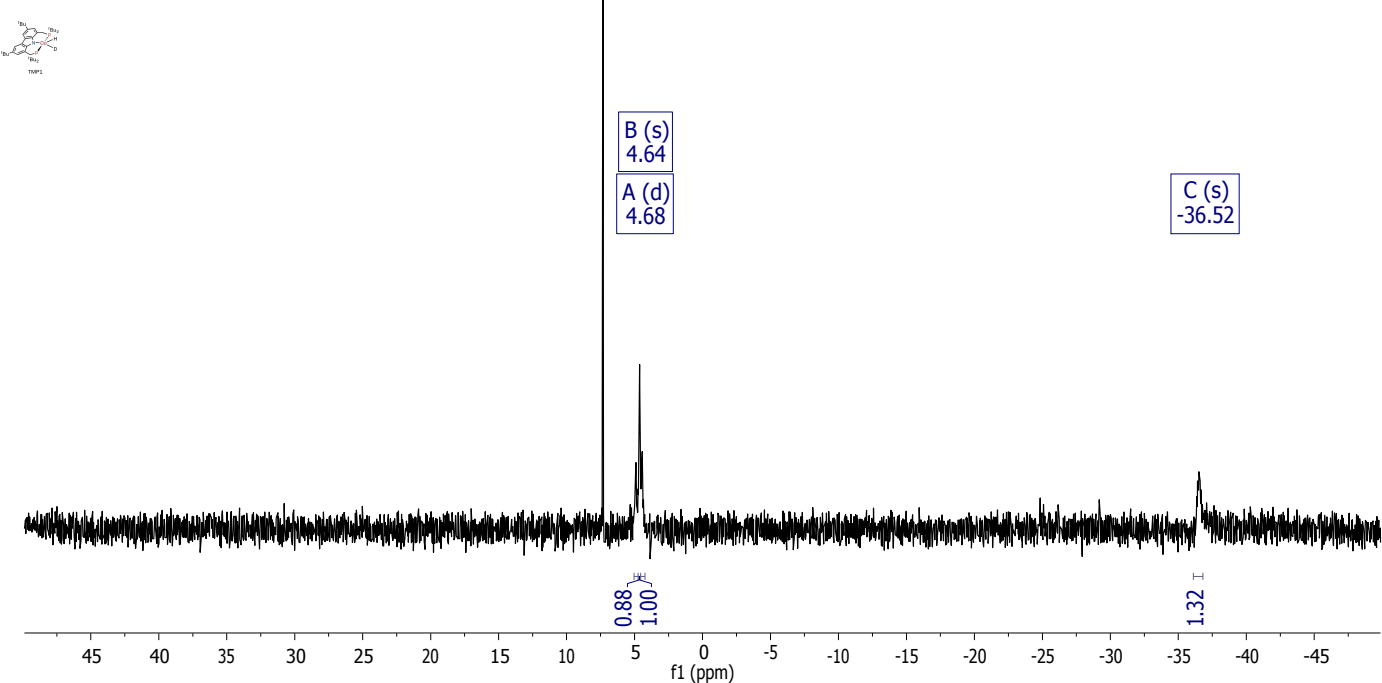



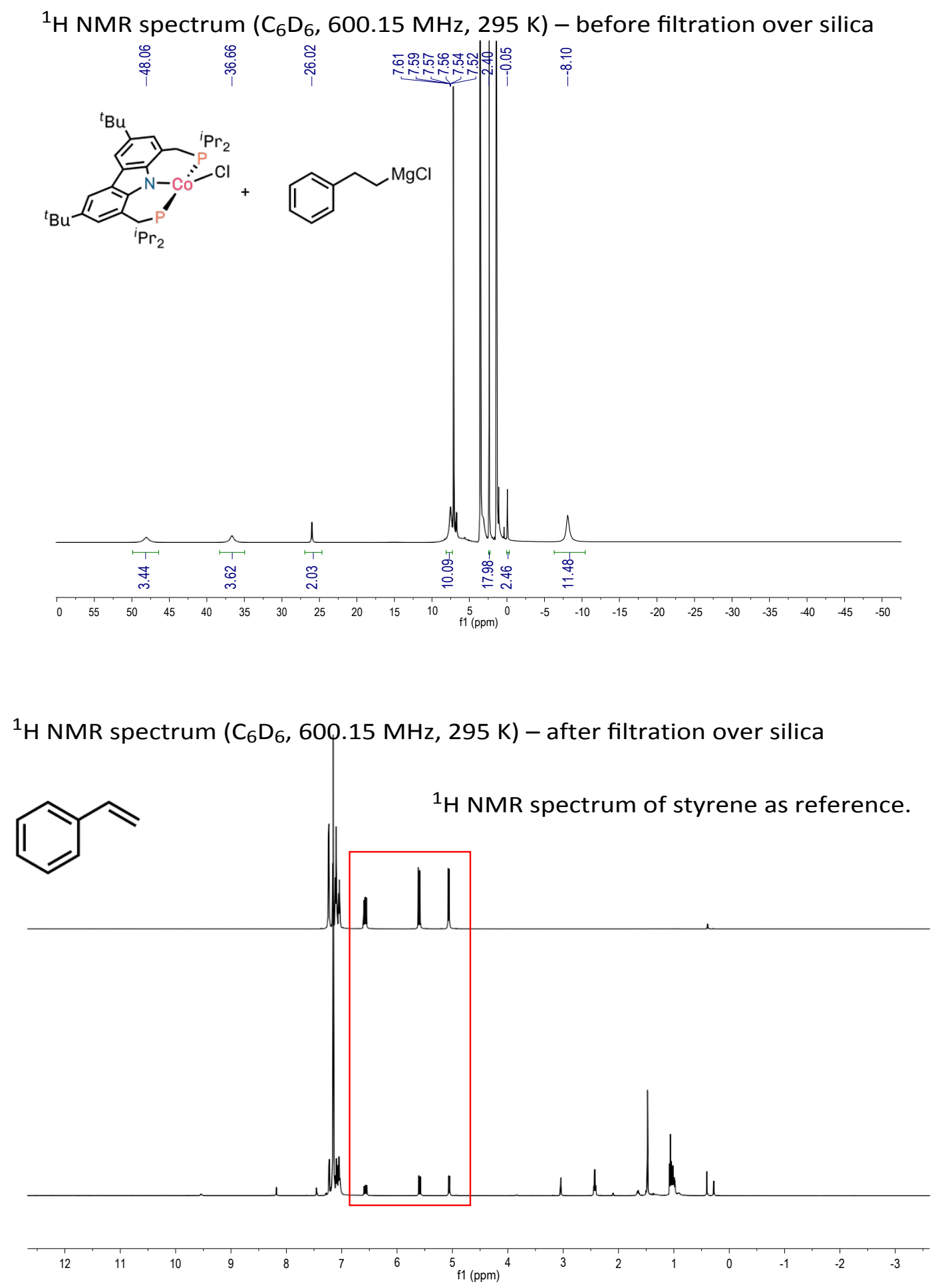


\section{IR Spectra}
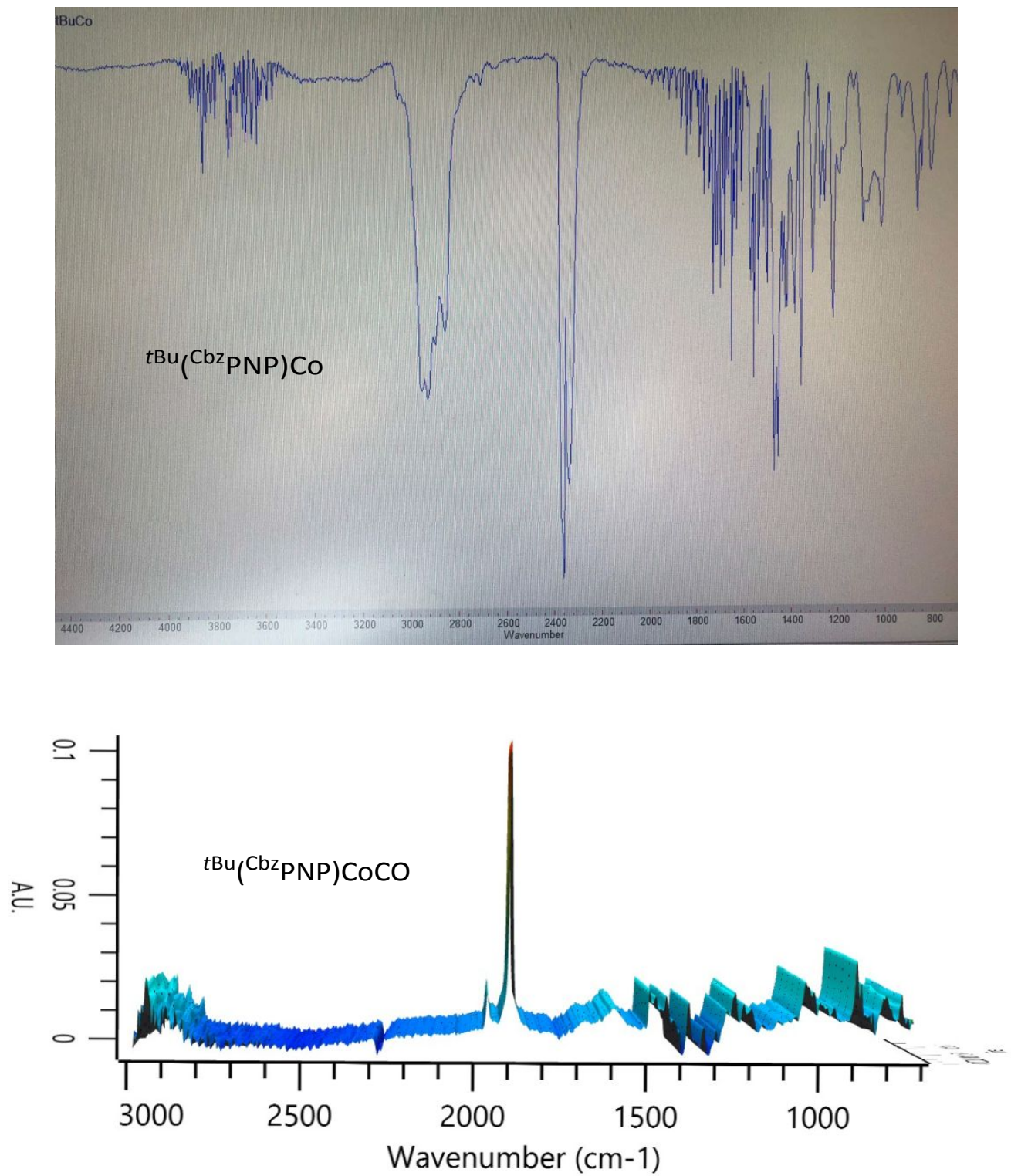

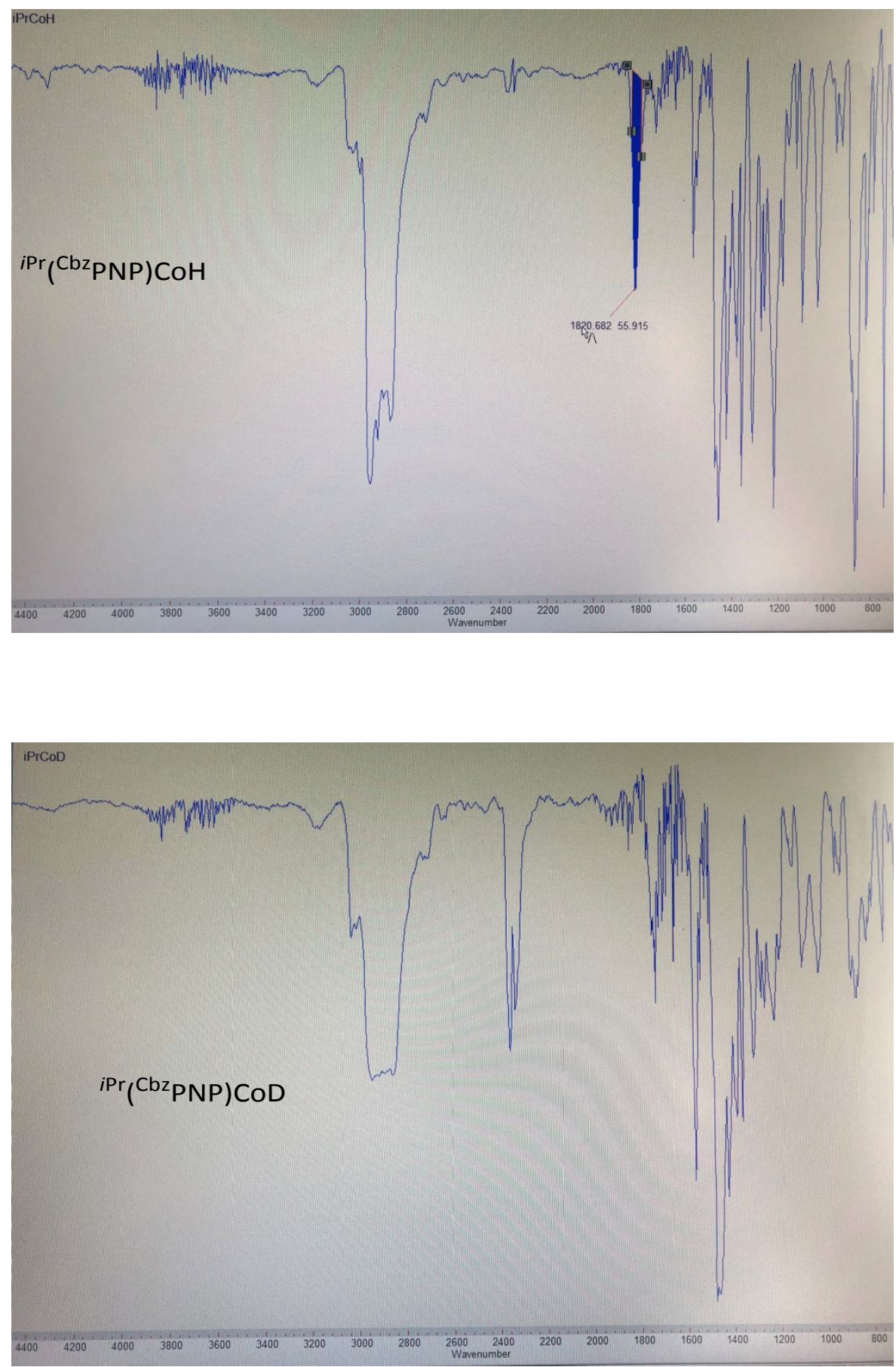


\section{References}

(1) Frisch, M. J.;Trucks, G.W.;Schlegel,H.B.;Scuseria, G. E.;Robb, M. A.; Cheeseman, J. R.; Scalmani, G.; Barone, V.; Mennucci, B.; Petersson, G. A.; Nakatsuji, H.; Caricato, M.; Li, X.; Hratchian, H. P.; Izmaylov, A. F.; Bloino, J.; Zheng, G.; Sonnenberg, J. L.; Hada, M.; Ehara, M.; Toyota, K.; Fukuda, R.; Hasegawa, J.; Ishida, M.; Nakajima, T.;Honda, Y.; Ki-tao, O.; Nakai, H.; Vreven, T.; Montgomery, Jr., J. A.; Peralta, J. E.; Ogliaro, F.; Bearpark, M.; Heyd, J. J.; Brothers, E.; Kudin, K. N.;Staroverov, V.N.;Keith, T.; Kobayashi, R.; Nor-mand, J.; Raghavachari, K.; Rendell, A.; Burant, J. C.; Iyengar, S. S.; Tomasi, J.; Cossi, M.; Rega, N.; Millam, J. M.; Klene, M.; Knox, J. E.; Cross, J. B.; Bakken, V.; Adamo, C.;Jaramillo, J.; Gomperts, R.; Stratmann, R. E.; Yazyev, O.; Austin, A. J.; Cammi, R.; Pomelli, C.; Ochterski, J.W.;Martin, R.L.; Morokuma, K.;Zakrzewski, V.G.;Voth, G. A.;Salvador, P.; Dannenberg, J. J.; Dapprich, S.; Daniels, A. D.; Farkas, O.; Foresman, J. B.; Ortiz, J. V.; Cioslowski, J.; Fox, D. J.Gaussian 09, Revision D.01., Wallingford CT, 2013.

(2) Becke, A. D. Density-functional thermochemistry. III. The role of exact exchange. J. Chem. Phys. 1993, 98, 5648-5652.

(3) Lee, C.; Yang, W.; Parr, R. G. Development of the Colle-Salvetti correlation-energy formulaintoa functional of theelectron density. Phys. Rev. B1988,37,785-789.

(4) Adamo, C.; Barone, V. Toward reliable density functional methods without adjustable parameters: The PBE0 model. J. Chem. Phys. 1999, 110, 6158-6170.

(5) Zhao, Y.; Truhlar, D. G. A new local density functional for main-group thermochemistry, transition metal bonding, thermochemical kinetics, and noncovalent interactions. J. Chem. Phys. 2006, 125, 194101.

(6) Kruck, M.;Sauer,D.C.;Enders, M.;Wadepohl,H.;Gade, L.H.Bis(2-pyridylimino)isoindolato iron(II) and cobalt(II) complexes: Structural chemistry and paramagnetic NMR spectroscopy. Dalton Trans. 2011, 40, 10406-10415.

(7) Kruck, M.; Wadepohl, H.; Enders, M.; Gade, L. H. Giant Residual Dipolar 13 C- 1 H Couplings in High-Spin Organoiron Complexes: Elucidation of Their Structures in Solution by 13CNMRSpectroscopy. Chem.Eur.J. 2013, 19, 1599-1606.

(8) Ott, J. C.; Blasius, C. K.; Wadepohl, H.; Gade, L. H. Synthesis, Characterization, and Reactivity of a High-Spin Iron(II) Hydrido Complex Supported by a PNP Pincer Ligand and Its 
Application as a Homogenous Catalyst for the Hydrogenation of Alkenes. Inorg. Chem. 2018, 57, 3183-3191.

(9) Ditchfield, R.; Hehre, W.J.; Pople, J. A. Self-Consistent Molecular-Orbital Methods. IX. An Extended Gaussian-Type Basis for Molecular-Orbital Studies of Organic Molecules. J. Chem. Phys. 1971, 54, 724-728.

(10) Weigend, F.; Ahlrichs, R. Balanced basis sets of split valence, triple zeta valence and quadruple zeta valence quality for $\mathrm{H}$ to $\mathrm{Rn}$ : Design and assessment of accuracy. Phys. Chem. Chem. Phys. 2005, 7, 3297-3305.

(11) Grimme, S.; Antony, J.; Ehrlich, S.;Krieg,H. A consistent and accurate ab initio parametrization of density functional dispersion correction (DFT-D) for the 94 elements H-Pu. J. Chem. Phys. 2010,132, 154104.

(12) Grimme, S.; Ehrlich, S.; Goerigk, L. Effect of the damping function in dispersion corrected density functional theory. J. Comput. Chem. 2011, 32, 1456-1465.

(13) Tomasi, J.; Mennucci, B.; Cammi, R. Quantum Mechanical Continuum Solvation Models. Chem. Rev. 2005, 105, 2999-3094.

(14) Ribeiro, R. F.; Marenich, A. V.;Cramer, C. J.; Truhlar, D. G. Use of Solution-Phase Vibrational Frequencies in Continuum Models for the Free Energy of Solvation.J. Phys. Chem. B 2011, 115, 4556-14562.

(15) Ignacio Funes-Ardoiz and Robert S. Paton. (2018, September 26). GoodVibes: version 2.0.3 (Version v2.0.3). Zenodo.

(16) Kaupp, M.; Köhler, F. H. Combining NMR spectroscopy and quantum chemistry as tools to quantify spin density distributions in molecular magnetic compounds. Coord. Chem. Rev. 2009, 253, 2376-2386.

(17) Kazansky, L. P.; McGarvey, B. R. NMR and EPR spectroscopies and electron density distribution in polyoxoanions. Coord. Chem. Rev. 1999, 188,157-210.

(18) Pennanen, T. O.; Vaara, J. Density-functional calculations of relativistic spin-orbit effects on nuclear magnetic shielding in paramagnetic molecules. J. Chem. Phys. 2005, 123, 174102.

(19) Pennanen, T. O.; Vaara, J. Nuclear magnetic resonance chemical shift in an arbitrary electronicspin state. Phys. Rev. Lett. 2008, 100,4-7. 
(20) Hrobárik, P.; Reviakine, R.; Arbuznikov, A. V.; Malkina, O. L.; Malkin, V. G.; Köhler, F. H.; Kaupp, M. Density functional calculations of NMR shielding tensors for paramagnetic systems with arbitrary spin multiplicity: Validation on 3d metallocenes. J. Chem. Phys. 2007, 126,024107.

(21) Bertini, I.; Luchinat, C. NMR of Paramagnetic Molecules. Coord. Chem. Rev. 1996, 150 , $1-292$.

(22) Sauer, D. C.; Kruck, M.; Wadepohl, H.; Enders, M.; Gade, L. H. Spin Density Distribution in Iron(II) and Cobalt(II) Alkyl Complexes Containing 1,3-Bis(2-pyridylimino)isoindolate Ligands. Organometallics 2013, 32, 885-892.

(23) Plundrich, G. T.; Wadepohl, H.; Gade, L. H. Synthesis and Reactivity of Group 4 Metal Benzyl Complexes Supported by Carbazolide-Based PNP Pincer Ligands. Inorg. Chem. 2016, 55, 353-365.

(24) Kabsch, K. in: Rossmann, M. G., Arnold, E. (eds.) “International Tables for Crystallography" Vol.F, Ch. 11.3, Kluwer Academic Publishers, Dordrecht, 2001.

(25) CrysAlisPro, Agilent Technologies UK Ltd., Oxford, UK 2011-2014 and Rigaku Oxford Diffraction, Rigaku PolskaSp.z o.o., WrocLaw, Poland 2015-2018.

(26) SCALE3 ABSPACK, CrysAlisPro, Agilent Technologies UK Ltd., Oxford, UK 2011-2014 and Rigaku Oxford Diffraction, Rigaku Polska Sp.z o.o., Wroclaw, Poland 2015-2018.

(27) Blessing, R. H. An empirical correction for absorption anisotropy. Acta Cryst. 1995, A51, 33-38.

(28) Busing, W. R.; Levy, H. A. High-speed computation of the absorption correction for single-crystal diffraction measurements. Acta Cryst. 1957, 10, 180-182.

(29) (a) Palatinus, L. SUPERFLIP, EPF Lausanne, Switzerland and Fyzikální ústav AVČR, v. v. i., Prague, Czech Republic, 2007-2014 (b) Palatinus, L.; Chapuis, G. SUPERFLIP - a computer program for the solution of crystal structures by charge flipping in arbitrary dimensions. J. Appl. Cryst. 2007, 40, 786-790.

(30) (a) Sheldrick, G. M. SHELXL-20xx, University of Göttingen and Bruker AXS GmbH, Karlsruhe, Germany 2012-2018; (b) Sheldrick, G. M. A short history of SHELX. Acta Cryst. 2008, A64, 112-122; (c) Sheldrick, G. M. Crystal structure refinement with SHELXL. Acta Cryst. 2015, C71, 3-8. 
(31) Müller, P.; Herbst-Irmer, R.; Spek, A. L.; Schneider, T. R.; Sawaya, M. R. in: Müller, P. (ed.) "Crystal Structure Refinement", Ch. 5, Oxford University Press, Oxford, UK, 2006.

(32) Jayatilaka D., Dittrich B. X-ray structure refinement using aspherical atomic density functions obtained from quantum-mechanical calculations. Acta Cryst. 2008, A64, 383393. 